\title{
Community seed network in an era of climate change: dynamics of maize diversity in Yucatán, Mexico
}

\author{
Marianna Fenzi ${ }^{1}$ (D) $\cdot$ Paul Rogé $^{2} \cdot$ Angel Cruz-Estrada $^{3} \cdot$ John Tuxill $^{4} \cdot$ Devra Jarvis $^{5,6}$
}

Accepted: 13 July 2021 / Published online: 25 July 2021

(c) The Author(s) 2021

\begin{abstract}
Local seed systems remain the fundamental source of seeds for many crops in developing countries. Climate resilience for small holder farmers continues to depend largely on locally available seeds of traditional crop varieties. High rainfall events can have as significant an impact on crop production as increased temperatures and drought. This article analyzes the dynamics of maize diversity over 3 years in a farming community of Yucatán state, Mexico, where elevated levels of precipitation forced farmers in 2012 to reduce maize diversity in their plots. We study how farmers maintained their agroecosystem resilience through seed networks, examining the drivers influencing maize diversity and seed provisioning in the year preceding and following the 2012 climatic disturbance (2011-2013). We found that, under these challenging circumstances, farmers focused their efforts on their most reliable landraces, disregarding hybrids. We show that farmers were able to recover and restore the diversity usually cultivated in the community in the year following the critical climate event. The maize dynamic assessed in this study demonstrates the importance of community level conservation of crop diversity. Understanding farmer management strategies of agrobiodiversity, especially during a challenging climatic period, is necessary to promote a more tailored response to climate change in traditional farming systems.
\end{abstract}

Keywords On-farm conservation $\cdot$ Landraces $\cdot$ Seed provision $\cdot$ Climate change $\cdot$ Agrobiodiversity

\section{Abbreviations \\ CEDRSSA Centro de Estudios para el Desarrollo Rural \\ Sustentable y la Soberanía Alimentaria \\ (Center for Studies on Sustainable Rural \\ Development and Food Sovereignty) \\ CIMMYT Centro Internacional de Mejoramiento de \\ Maíz y Trigo (International Maize and \\ Wheat Improvement Center)}

CONAGUA Comisión Nacional del Agua (National Water Commission)

INEGI Instituto Nacional de Estadística y Geografía (National Institute of Statistics and Geography)

SIAP Servicio de Información Agroalimentaria y Pesquera (Service Agrifood and Fisheries Information
Marianna Fenzi

marianna.fenzi@epfl.ch

Paul Rogé

proge@berkeley.edu

Angel Cruz-Estrada

angel_estrad@yahoo.com.mx

John Tuxill

tuxillj@wwu.edu

Devra Jarvis

devra.jarvis@agrobiodiversityplatform.org

1 École Polytechnique Fédérale de Lausanne, Laboratory for the History of Science and Technology, Route Cantonale, 1015 Lausanne, Switzerland
2 Environmental Science, Policy, and Management, University of CA - Berkeley, Mulford Hall, 130 Hilgard Way, Berkeley, CA 94720, USA

3 Centro de Innovación para el Desarrollo Apícola Sustentable, 77870 Municipio de José María Morelos, Q ROO, Mexico

4 Fairhaven College of Interdisciplinary Studies, Western Washington University, Bellingham, WA 98225, USA

5 Platform for Agrobiodiversity Research, Museo Orto Botanico di Roma-Universita' La Sapienza c/o SARA ENViMOD, Largo Cristina di Svezia, 23 A - 24, Rome, Italy

6 Department of Crop and Soil Sciences, Washington State University, Pullman, USA 


\section{Introduction}

The exchange and marketing of seeds among farmers continue to shape crop populations across the Global South (Almekinders et al. 1994; Coomes et al. 2015; McGuire and Sperling 2016). Much of the world's farming population continues to rely on landraces, also called farmer varieties or traditional varieties, to meet their production needs (Jarvis et al. 2008, 2011; López-Noriega et al. 2012). Agricultural adaptation strategies based on agrobiodiversity predominantly depend on the seed system's ability to provide adaptive materials to the rapidly changing climate (FAO 2019). In Mexico, as elsewhere, maize seed provisions is a social process in which farmers are making decisions about the most appropriate maize varieties for their needs. Farmers may decide to preserve landraces, replace some of them with new varieties, or improve the local maize diversity by introducing novel sources of diversity, such as adapting commercial varieties to their needs (Dyer and Taylor 2008). Supporting seed networks among farmers with local and new varieties is fundamental to a successful climate adaptation strategy attentive to farmers' needs (Bellon and van Etten 2014; Hellin et al. 2014). This strategy requires an understanding of seed management, which can adapt the availability of crop diversity to new conditions (López-Noriega et al. 2012).

Quantitative data analysis on seed lot transactions between farmers (seed flow) across time in Mexico is lacking (Dyer and López-Feldman 2013). To our knowledge, even less is known on how farmers respond to critical climate events through their seed network. In this work, we studied the management of maize (Zea mays) landraces in a Yucatán village analyzing the functioning of seed flow over 3 years, from 2011 to 2013. In 2012, unusually heavy precipitation at a key point in the annual agricultural cycle forced farmers to limit their cultivated surface, and, consequently, the array of varieties sown. The aim of the study was to understand the influence of seed dynamics on maize diversity and how these dynamics contributed to the conservation of maize diversity after a critical climate event. The results provided insights to approach future trends in in-situ conservation of crop genetic diversity, genetic erosion, and the management of crop diversity under changing conditions.

\section{Climate change and genetic resources}

Local seed systems remain the fundamental sources of seeds for many crops in developing countries (Almekinders and Louwaars 1999; Tripp 2001; Altieri 2002; Halewood et al. 2012). Climate change has significant effects on agricultural productivity, changing ecosystems and the geography of crop suitability (Lane and Jarvis 2007; Porter and Xie
2014; Vermeulen et al. 2018). Variability in the timing of rainfall and intensity of heavy precipitation events in the southern United States, detected since 1901, are projected to continue to increase over the twenty-first century (Easterling et al. 2017). The anomalies in growing season temperatures and precipitation patterns can be detrimental to food security (Lobell et al. 2008, 2011). To deal with future climatic conditions, new solutions integrating genetic diversity in plant breeding approaches are urgently needed (Naylor et al. 2007; Lobell et al. 2008; Mutekwa 2009; Ceccarelli et al. 2010). This includes the importance of understanding the functioning of the local seed supply systems to better support the design of genetic resources conservation (Maxted et al. 2002; Zimmerer 2003; Bellon 2004), within operational strategies enhancing different actors involved in agricultural efforts (López-Noriega et al. 2012; Jackson et al. 2013).

Tropical and sub-tropical areas are subject to severe climate change impacts on agriculture, and crop growth models indicate greater yield losses for maize in rainfed maize regions, including Mexico (Rosenzweig et al. 2014). Smallscale maize farmers' capacities to manage climatic risk in already vulnerable rural areas is greatly influenced by the kind of adaptation strategies implemented via agricultural policies (Eakin 2005). ${ }^{1}$ Given the controversial aspects of using transgenic maize seeds to adapt to climate change, especially in the center of origin of maize, ${ }^{2}$ scholars have highlighted the need for specific agronomic interventions directed at strengthening the adaptive capacity of local varieties (Bellon and Berthaud 2006; Mercer 2012). Adopting this perspective, scholars have stressed the importance for Mexico to look at farmers' stewardship of maize landraces when designing climate change adaptation initiatives (Hellin et al. 2014).

It is extremely difficult to model or predict the impact of climate change on smallholder and subsistence agriculture given the intrinsic complexity of these systems and their local specificity (Morton 2007). Some studies show that farmers are keenly aware of changes in their local climate, such as changes in precipitation patterns, and they have changed their practices and crop choices as a result (Olesen et al. 2011; Abidoye et al. 2017). However, there is a lack of knowledge about farmers' strategies to deal with climatic variability regarding their management of intra-specific crop

\footnotetext{
1 With "small-scale maize farmers" we refer to smallholdings in Mexico, since the majority of the household agricultural production units have an area equal or less than three hectares. See: INEGI (2009), Lazos and Chauvet (2011), Perales (2016).

2 Several transgenic crops are cultivated in Mexico, including cotton and soybean. However, in December 2020 a federal government decision banned genetically modified maize. See the Official Gazette of the Mexican Federation (Article 6) https://www.dof.gob.mx/nota detalle.php?codigo $=5609365 \&$ fecha $=31 / 12 / 2020$.
} 
diversity in the form of diverse sets of crop varieties (Jarvis et al. 2007; Mijatović et al. 2013; Altieri and Nicholls 2017). The great genetic diversity and biological plasticity of maize landraces together with farmers' seed management has the potential to play an important role in farmers' strategies to deal with the negative impacts of climate variability (Eakin 2005, 2006; Mercer and Perales 2010; Rogé et al. 2014).

\section{Maize landraces in Mexico}

Although commercial hybrid maize is planted in large-scale agriculture systems worldwide, maize landraces continue to play an important role in Mexico. Cultivating maize landraces is a livelihood strategy that, in some areas, best meets the production needs and the cultural preferences of farmers, creating a "culture of maize" (Perales et al. 1998, 2003a, b, 2005; Lerner and Appendini 2011; Lazos Chavero 2013; Eakin et al. 2014; Orozco-Ramírez and Astier 2017). According to estimations by the International Maize and Wheat Improvement Center (CIMMYT) of commercial seeds produced, $61 \%$ (Donnet et al., 2012) to $79 \%$ (Aquino et al., 2001) of seeds employed by farmers each year come from saved seed lots (including landraces, mixtures, and advanced generations of hybrids). These data have been used as a reference in several studies (Perales 2016; Bellon et al. 2018). The estimation made by the Center for Studies on Sustainable Rural Development and Food Sovereignty (CEDRSSA), based on a national survey not specific to maize, estimates the maize area planted with saved seeds at around 45\% (CEDRSSA 2018). In rain-fed areas, hybrid maize adoption has been limited since they are less competitive under many farmers' production conditions, compared to landrace populations that have wider plasticity to genotype-by-environment interactions (Perales et al. 1998, 2003b; Bellon et al. 2005; Brush and Perales 2007; Bellon and Hellin 2011; Keleman et al. 2013; Hellin et al. 2014; Orozco-Ramírez et al. 2016; Perales 2016; Fenzi et al. 2017). In Yucatán, local storage conditions appear to be a key factor pushing against the adoption of hybrids: local landraces present a thick, multi-layered husk completely covering the ear, a characteristic that hybrids lack, making them more vulnerable to insect pests during storage (Moreno et al. 2006).

Maize culture by smallholder farmers persists in Mexico because it reduces market dependency and is easily integrated into diversified multi-activity household income strategies (Ewell and Merrill-Sands 1987). However, many factors can affect local maize dynamics: farmers, when possible, are shifting to other production systems (Astier et al. 2020) or looking for off-farm income, including seasonal or permanent migration from rural areas to cities (Schüren 2003; Fitting 2006; Lazos Chavero 2013; Pérez-Ruiz 2015). Land-use changes and the resulting decrease in areas planted to maize play a major role in genetic erosion. This phenomenon is also related to difficulties in trading maize on markets and with the growing use of commercially processed maize flour instead of local grain to make tortillas (Ortega-Paczka 2003; Orozco-Ramírez et al. 2016; McLean-Rodríguez et al. 2019). Genetic erosion is an ongoing and complex process whose extent and accountability are still a matter of debate (Van Heerwaarden et al. 2010). Contrasting results from different studies show the complex dynamics of maize landrace distribution and conservation and the difficulties of drawing broad conclusions (Dyer et al. 2014; Perales and Golicher 2014; Brush et al. 2015; Orozco-Ramírez et al. 2017; McLean-Rodríguez et al. 2019).

A range of factors, including altitude, are associated with the spatial distribution of maize landraces and climate change, reducing the areas with favorable conditions for their cultivation, and threatening each landrace at different intensities (Ureta et al. 2012, 2013). In warmer environments and lower elevations of Mexico, landraces have been generally displaced by commercial varieties (Ortega-Paczka 2003; Brush and Perales 2007) and climate change is likely to play an increasing role in their reduction (Mercer and Perales 2010). Rain-fed agriculture in sub-tropical regions of Mexico is deeply influenced by critical climatic phenomena (Conde et al. 2006). How climate change impacts maize diversity and imposes variation in population size, richness and therefore genetic structure is a matter of concern (Mercer and Perales 2010; Bellon et al. 2011; Mercer 2012). In the last decade, several studies brought attention to the effects of climate change on maize diversity in Mexico (Mercer and Perales 2010; Bellon et al. 2011; Bellon and van Etten 2014; Hellin et al. 2014). Projections show a likely decrease in the potential distribution of landraces in Mexico by 2030 (affecting 43 out of 47 races) as a consequence of climate change (Ureta et al. 2012), the highest decrease being expected for those races which already have a restricted distribution in medium-level annual precipitation areas. Due to the changes induced by climate variability, it is important to look at farmers' seed dynamics to predict future scenarios of distribution and availability of crop diversity to design new conservation and breeding strategies.

\section{Local seed system}

Mexico is the center of origin of maize and has the greatest genetic diversity of maize worldwide, with around 59 races and thousands of varieties described to date (Kato et al. 2009). The differentiation among maize races and within them, as well as their adaptation to various agroecosystems, is the result of both natural and human selection (Fedoroff 2003; Doebley 2004). Many studies conducted by biologists and social scientists have revealed how the heterogeneity of farmers' crop management, including 
farmers' seed networks, influences crop diversity (Jarvis 2005; Smale 2005; Hodgkin et al. 2007; Jarvis et al. 2007; Thomas et al. 2011; Pautasso et al. 2013). In Mexico, seed flow is an important factor in shaping geographical distributions of maize diversity and its genetic structure (Doebley 2004; van Etten and de Bruin 2007). Seed replacement, introduction, and diffusion differ significantly across regions and altitudinal zones in Mexico (Dyer and López-Feldman 2013). Maize phenotypic diversification evolves in combination with farmers' seed management and selection strategies (Brush 1995; Pressoir and Berthaud 2004; Bellon and Hellin 2011). Studies of seed systems have investigated especially the persistence and evolution of landraces in relation to the introduction of modern varieties (Bellon and Taylor 1993; Bellon and Brush 1994; Dusen and Eric 2000; Perales et al. 2003b). They found that the advanced generations of commercial varieties have been 'creolized': they lose certain characteristics and retain some of their advantages while they show greater adaptation to local conditions (Bellon and Risopoulos 2001; Perales et al. 2003a). Farmers can also allow hybridization between modern and local varieties, thereby merging new sources of diversity and eventually suitable characters in the local population (Almekinders et al. 1994; Morris et al. 1999; Louette and Smale 2000; Badstue et al. 2005; van Etten and de Bruin 2007). Seed system networks are mainly structured around the community in a context of mutual interdependence and trust (Almekinders et al. 1994; Badstue et al. 2006; Brush and Perales 2007). The participation of farmers to ensure their access to a larger array of maize diversity has been described as a form of collective action (Badstue et al. 2006). However, less widely investigated is the potential role of seed networks in the conservation of crop diversity during difficult climate events. In this work, our aim was to assess the dynamic of maize diversity conservation across time analyzing farmers' choices in terms of varieties and seed management practices in response to a challenging climate event.

We addressed several interrelated questions: How do changing rainfall patterns influence farmers' practices? How do farmers recover from challenging events to reintroduce diversity in their fields? Which maize varieties are considered to be more reliable by farmers, and which ones are disregarded under challenging conditions? What is the impact of seed flow on the conservation of maize diversity?

\section{Materials and methods}

\section{Study site}

Yaxcabá is one of the 106 Yucatán municipalities, encompassing approximately $1474 \mathrm{~km}^{2}$ (Fig. 1A). Yaxcabá village is the main population center within the municipality. The village is located in the middle of the zona maicera (maize producing zone) of Yucatán state, $108 \mathrm{~km}$ east-southeast of Merida, the capital city of the state. The rural population in Yaxcabá is predominantly Yucatec Maya in ethnicity and culture, and small-scale milpa agriculture ${ }^{3}$ retains an important presence on the landscape (Pérez-Ruiz 2015). The region has a seasonally dry tropical climate with a mean annual precipitation of $1024 \mathrm{~mm}$ and a mean annual temperature of $26^{\circ} \mathrm{C}$. Temperature and altitudinal gradients are homogenous throughout the municipality of Yaxcabá. The major source of agroecological heterogeneity relates to soil differences. Similar to farmers in Chiapas State and other areas of Mexico (Bellon 1991; Bellon and Taylor 1993), milpa farmers in Yaxcabá have deep knowledge about the relationship of their maize varieties performances based on soil type and quality, which determines which maize varieties to plant in which soil type (Fenzi et al. 2017). The main factor influencing annual production is the distribution of rainfall, including its intensity and timing. The Yucatán peninsula has frequently been affected by extreme climate events, such as the hurricanes Gilberto in 1988 and Isidoro in 2002, both of which caused serious damage to the agricultural system. According to farmers in Yaxcabá, in recent years the changes in the rainfall regime across the region have pushed many farmers to delay the time of sowing from May to June.

In Yaxcabá there are about 460 ejidatarios,${ }^{4}$ and at the time fieldwork was carried out, only about 200 of the ejidatarios in Yaxcabá were growing maize (milpa). However, in 2011 according to reports by farmers in informal discussions, around 100 farmers who did not have formal ejidatario status also planted milpas on the ejido's lands. The area of milpa cultivated annually in the entire Yaxcabá municipality is estimated at approximately 8000 ha (SIAP 2011). The mean production is 0.69 ton/ha of maize (SIAP 2011) sometimes cultivated in association with beans (Phaseolus vulgaris and Phaseolus lunatus) and squash (Cucurbita moschata and Cucurbita argyrosperma).

\footnotetext{
${ }^{3}$ Milpa is a Mesoamerican polyculture system where the most common association is maize, squash, and beans. In Yaxcabá and in many regions of Mexico, milpa refers also to maize cultivation, and farmer can call a plot a milpa where they grow only maize.

${ }^{4}$ The ejidatarios have usufruct rights on common land (ejido) but the lands cannot be sold, rented, or mortgaged. The ejido is a community of peasants that received a land grant from the federal government of Mexico under constitutionally mandated Agrarian Reform (1915-1992). In 1992, a series of reforms to Article 27 of the Mexican Constitution became law. Among the key provisions of this reform are the right of ejidatarios to sell, rent or mortgage their land parcels which were previously inalienable and thereby potentially opening these lands for private capital investment.
} 
Fig. 1 Monthly precipitation estimates in Yaxcabá. A Representation of Yaxcabá municipality (light red) and Yaxcabá village (dark red). The three communities (Valladolid, Ticul, and Peto) whose precipitation data have been employed to calculate the monthly precipitation estimates in Yaxcabá are depicted in dark gray. Scale bars in miles and kilometers are depicted. Shapefiles were obtained from INEGI and GADM. B Monthly precipitation estimates in Yaxcabá in 2011 (green line), 2012 (red line), and 2013 (blue line). The dark gray line represents the mean monthly precipitation estimates from 1960 to 2010. The light gray dotted line indicates the minimum and the light gray dashed line indicates the maximum monthly precipitations through this period
A

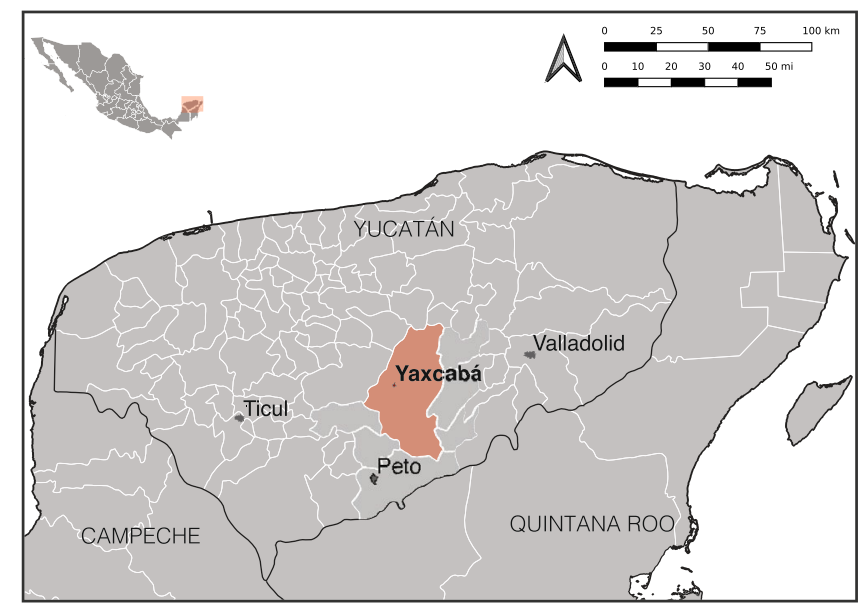

B

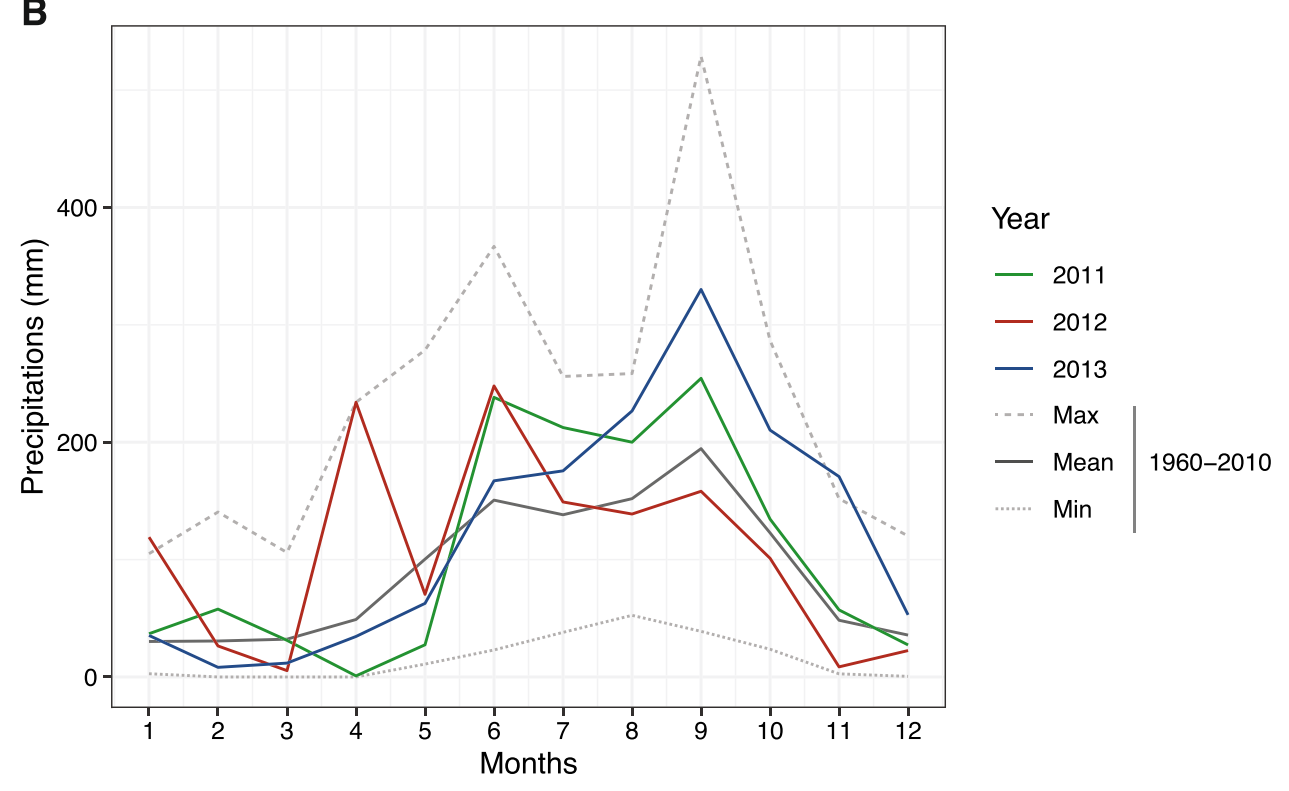

\section{Study design}

Through a 3-year survey, from 2011 to 2013, we prospectively collected data to estimate the on-farm maize varietal diversity and documented seed movements across and from Yaxcabá village. We use the term "community" to indicate Yaxcabá village itself and "other communities" to indicate smaller villages nearby that are also part of the Yaxcabá municipality. The interviews were conducted in three different periods (thereby capturing seed flow information across three annual cropping cycles). From April 4th to October 17th, 2011, we interviewed 71 farmers. In 2012, from June 7 th to September 28th, we re-interviewed 68 out of the 71 farmers interviewed in 2011. In 2013, from June 10th to November 25th, we re-interviewed 62 farmers from the original list of farmers from 2011. All but one of the missing farmers in 2012 and 2013 stopped cultivating their milpa because of retirement or personal reasons. Some of them have been replaced by close family members who were not included in this study. One farmer did not cultivate milpa in 2012 because of personal reasons but started again in 2013 .

Farmers included in the present study were initially selected in 1999 through a random selection of households stratified by geographic quadrants within Yaxcabá town (Jarvis et al. 2008; Tuxill et al. 2010). Parts of the results of the interviews performed in 2011 were included in our previous report (Fenzi et al. 2017). We developed a survey questionnaire in Spanish accompanied by a translation into Yucatec Maya (questionnaire available in Supplemental material). The questionnaire primarily focused on questions about which crops are cultivated by the households, including the location of the farmer's milpa within the ejido, and the size of each plot for each maize variety. To assess the dynamics of maize diversity in Yaxcabá over 3 years, we 
analyzed and compared maize variety richness and evenness, which are two key concepts in biological diversity assessment (Magurran 2013; Jarvis et al. 2008). Richness was measured as the total number of maize varieties grown in each farmer's plot. Evenness describes the relative abundance of the different varieties within each farmer's plot. We measured evenness, according to Magurran (2013), as the complement $(1-D)$ of Simpson's Index. ${ }^{5}$ Richness and evenness include all different varieties of maize that were found in the village, including landraces, the locally improved variety Nal Xoy, Mejorado and Híbrido.

A second part of the survey was devoted to information about maize seed lots. We asked about the origin of each lot, the typology of the acquisition and the quantity. The amount of seeds needed by each farmer was calculated considering the sowing density that is specific to each maize variety and each farmers' cultivated surface with those varieties. We also investigated farmer preferences about seed sources (outside the household) and factors influencing their choices. In 2013 we asked for the name of the farmers to whom interviewed farmers gave seed lots or from whom they received seed lots. In 2013, we also asked every farmer to provide us the names of farmers from whom, in case of need, they would request seeds. We collected agronomical and socioeconomic information to provide additional elements on patterns in decision making about maize management (jobs, governmental aids, cost of the milpa, uses of maize). In addition to quantitative surveys, we acted as participant observers during different phases of the milpa cycle, including sowing, harvest, storage for conservation, and seed preparation. The interviews generally lasted between one and three hours, and in most cases were completed with a visit to the farmer's field.

\section{Precipitation data}

Precipitation measures were obtained from the Comisión Nacional del Agua (National Water Commission) (Conagua). As no information about rainfall was routinely collected in Yaxcabá by Conagua, we estimated precipitations in Yaxcabá using daily rainfall measurements from 1960 to 2013 for the three closest localities with complete data. They are, in proximity to Yaxcabá, Valladolid $(66 \mathrm{~km})$, Peto $(48 \mathrm{~km})$, and Ticul $(75 \mathrm{~km})$ and are represented in dark gray in the Yucatán map (Fig. 1A). The map was created on QGIS 3.10 (https://www.qgis.org/) and the data sources are INEGI (https://www.inegi.org.mx/) and GADM (https://gadm.org/).

\footnotetext{
${ }^{5}$ Simpson's Index: $\mathrm{D}=\Sigma(\mathrm{n} / \mathrm{N}) 2$ where $\mathrm{n}$ is the total number of organisms of a particular species and $\mathrm{N}$ is the total number of organisms of all species.
}

\section{Maize diversity classification}

According to the definition of Louette et al. (1997), we also use the term "variety" to refer to the different seed lots sown by farmers who differentiate them as a distinct maize type. Additionally, we consider "seed lot" to mean all kernels of a specific type of maize selected and reproduced by a farmer (Louette et al. 1997).

In Mexico, farmers usually devote most of their land to one maize variety, showing that diversity is constituted by major (or dominant) and minor varieties (Perales 1998; Lazos Chavero 2013; Brush and Perales 2007; Perales and Hernández-Casillas 2005). Agro-morphological studies have identified several different maize genetic groups in Yaxcabá municipality (Ortega Paczka and Dzib Aguilar 1992; Zizumbo Villarreal et al. 1992; Arias Reyes et al. 2004; Dzib Aguilar et al. 2016): an early maturing landrace group of 62-72 days (local varieties Nal t'eel, $x$-T'uup nal and $x$-Mejen nal), a late group of 83-90 days (Ts' ' ' 'it bakal and $x$-Nuuk nal varieties) within the Tuxpeño landrace, and intermediate groups composed of locally adapted (Mejorado) and locally improved (Nal-Xoy) varieties originally released by plant breeding programs. With the term landrace we refer to all local farmer-maintained varieties with historical origins and cultural significance that have not undergone formal scientific plant breeding (Villa et al. 2005). Most maize landraces in Yucatán occur in yellow, white and blue kernel variants, and farmers usually do not mix seeds of different colors.

We consider an improved variety (like hybrids and some open-pollinated varieties) to be a variety that has been selected by professional plant breeders, usually in experimental stations. Improved varieties have been available in the region for at least the last 40 years and some of them have been introduced in Yaxcabá. Farmers can creolize improved varieties, planting them year after year and allowing or creating favorable conditions for gene flow between them and the local germplasm (Bellon and Risopoulos 2001; Perales et al. 2003a; Cleveland and Soleri 2007). Furthermore, new populations can be developed under natural and farmer selection for specific traits (Bellon 1991; Badstue et al. 2006; Dyer and Taylor 2008). We consider Mejorado as a creolized variety as defined by Bellon and Risopoulos (2001). Mejorado is an advanced generation of an improved variety that has been adapted to farmers' environments by farmers and natural selection. In addition, Nal Xoy is a locally improved maize variety created by a farmer in the village of Xoy, Yucatán, as part of an official breeding program in the 1980s. Nal Xoy, originated as a cross between the modern variety PR-7822 and the local maize Nal t'eel (Chávez-Servia et al. 2002), arrived in Yaxcabá as a previously creolized variety, which local farmers have continued to select and adapt in the same way they manage their landrace populations. We consider 
Híbrido any recently introduced, not creolized commercial hybrid.

\section{Data analysis}

Data were analyzed and visualized using $\mathrm{R}$ version 4.0.2 (Comprehensive R Archive Network project: http://cran. us.r-project.org), and R studio version 1.3.1056. Graphs were generated using the 'ggplot2' package version 3.3.3. Cross-sectional analyses involving two groups were performed using the non-parametric Mann-Whitney U test ('stat_compare_means' function of the 'ggpubr' package version 0.4.0). Cross-sectional analyses involving more than two groups were performed using the non-parametric Kruskal-Wallis test with Dunn's multiple comparisons tests ('dunn_test' function of the 'rstatix' package version 0.7.0). Correlation analyses were performed using the non-parametric Spearman's rank test ('stat_cor' function with the 'spearman' method of the 'ggpubr' package version 0.4.0).

\section{Results}

\section{Exceptionally heavy precipitations in 2011}

Farmers unanimously claimed that unusually heavy rains in the spring of 2012, before the start of the typical rainy season, affected the period mainly dedicated to the preparation of field through the roza, tumba y quema process (slash-andburn agriculture). This process allows farmers to clear (or "clean" in Yaxcabá farmers' terminology) a planting surface efficiently and provides nutrients to the soil through ashes from the controlled burns. Farmers pointed out that the particular climate conditions in 2012 rendered the cleaning process with fire ineffective and often impossible, resulting in a reduced surface available for milpa planting. Most farmers emphasized in interviews that they drastically reduced their area of milpa sown in 2012 compared to 2011. As a result, many of them were able to only plant the plots that were already clean or that did not require fire. A farmer pointed out during the interview the following year: "Once everything is dry in April, we clean the plot with the fire. Last year the rain came before we burned down. There weren't many who could burn in March, the majority of us still had to do that and we couldn't. This year [2013] in Yaxcabá, we burned in March, out of fear".

In order to quantify rainfall variation in 2011, 2012, and 2013 in Yaxcabá and compare with those of previous years, we calculated monthly precipitation from 1960 to 2013 (Fig. 1B). The data show a drastically higher monthly precipitation in April of 2012 (234 mm, red line) compared to 2011 (0.9 mm, green line), 2013 (34.54 mm, blue line), and the mean from 1960 to 2010 (45 mm, gray line). This anomaly observed in 2012 was exclusively limited to April, with the abundance of rain during the remaining months of the year being comparable to that of other years (Fig. 1B). Importantly, the very intense rain in April 2012 can be considered as a very exceptional event, given that from 1960 to 2010 only 1 year (1989) registered an equivalent amount of rain in April (Supplemental Fig. 1).

\section{Loss of milpa surface and maize diversity dynamics}

Farmers' interviews indicated that the strong rainfall events in April 2012 had an impact on their ability to prepare the soil for sowing. The land area allocated to milpa cultivation was significantly reduced in 2012 (median [range] $=2$ [0-4.4] Ha) compared to $2011(3[0.76-6.28] \mathrm{Ha}, \mathrm{p}=0.0002)$ and 2013 (2.6 [0-7.56] Ha, p=0.004; Fig. 2A, left panel). Assessing the dynamic of maize diversity in Yaxcabá over 3 years, we observed a significantly reduced richness (1 [0-3]; Fig. 2A, middle panel) and evenness (0 [0-0.66]; Fig. 2A, right panel) in 2012 compared to both 2011 (richness: 2 [1-6], $\mathrm{p} \leq 0.0001$; evenness: 0.44 [0-0.75], $\mathrm{p}<0.0001)$ and 2013 (richness: 2 [1-5], $\mathrm{p} \leq 0.0001$; evenness: 0.43 [0-0.68], $\mathrm{p}<0.0001$ ). A direct relationship between the size of the cultivated area and the diversity estimates was further indicated by correlation analysis. In 2011 we observed a trend, not reaching statistical significance but pointing to a positive correlation between the cultivated surface and maize richness (Spearman's rank correlation coefficient $r=0.23$, $\mathrm{p}=0.052$; Fig. 2B). However, in 2012 and 2013 we observed a significant positive correlation between these two parameters $(2012 \mathrm{r}=0.48, \mathrm{p}<0.0001 ; 2013 \mathrm{r}=0.33, \mathrm{p}=0.008$; Fig. 2B). We found similar results when the relationship between the cultivated surface and maize evenness was assessed $(2011 \mathrm{r}=0.04, \mathrm{p}=0.74 ; 2012 \mathrm{r}=0.41, \mathrm{p}=0.00043$; $2013 r=0.3, p=0.017$; Fig. $2 C$ ).

To further investigate the impact of the reduction of cultivated surface on maize diversity conservation, we calculated the percentage of area cultivated with each maize variety over the 3 years (Fig. 3). We observed a relatively steady distribution of traditional varieties (X-nuuk nal Blanco, X-nuuk nal Amarillo, X-e'-jub, Ts'iit-bakal Blanco, Ts'iitbakal Amarillo, X-T'uup nal Blanco, X-T'uup nal Amarillo, $X$-Mejen nal Blanco, X-Mejen nal Amarillo, Nal t'eel) and locally improved or locally adapted varieties (Nal-Xoy, $\mathrm{Mej}$ orado) during the 3 years (Fig. 3). However, we observed a significant reduction in the surface area allocated to the cultivation of the hybrid variety (Híbrido) in 2012 compared to $2011(p=0.001)$ and $2013(p=0.037$; Fig. 3). Interestingly, with the exception of the already rarely grown Nal t'eel, all the varieties listed in Yaxcabá in 2011 were found in the 2012 survey (Fig. 3).

Supplemental Fig. 2 shows the dynamics of varieties cultivated by each farmer during the 3 years. We observed 
A
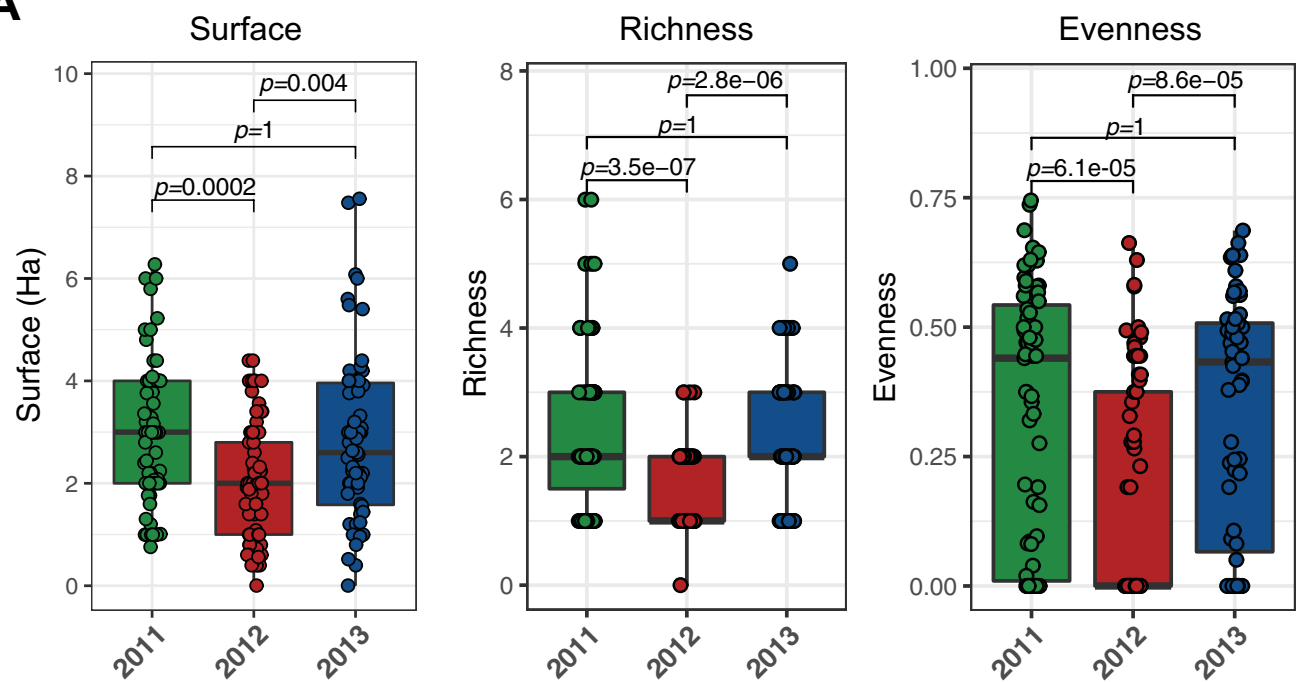

Year

투 2011

투 2012

후 2013
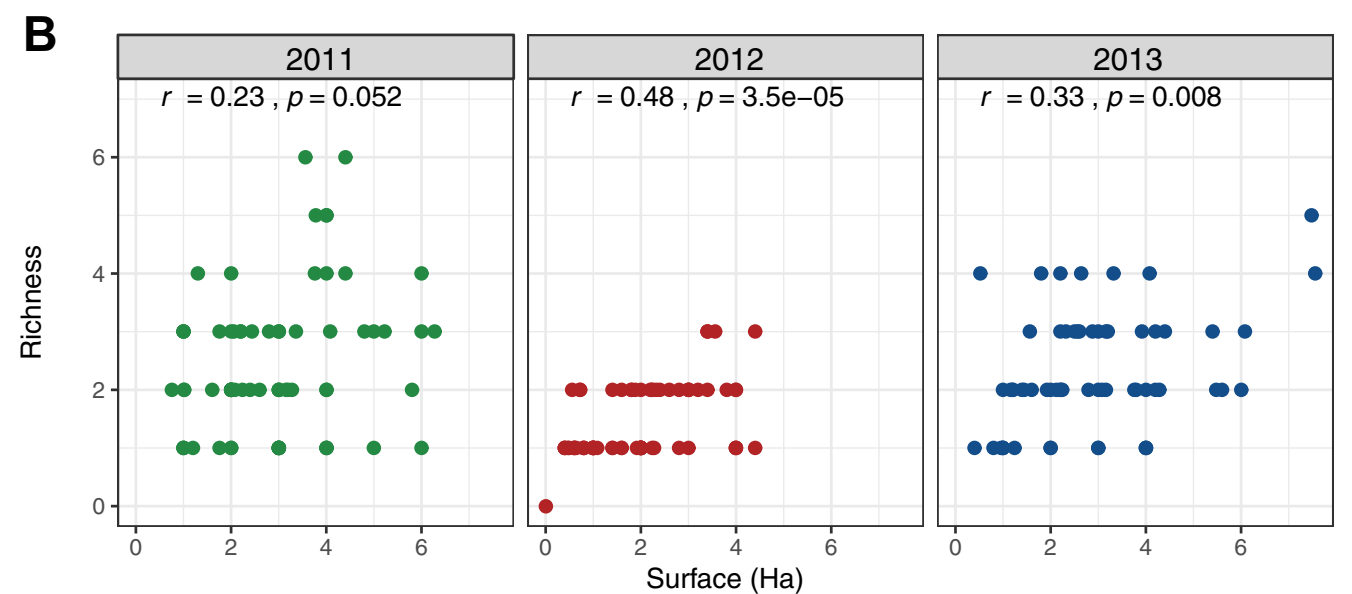

Year

$$
\begin{aligned}
& -2011 \\
& -2012 \\
& -2013
\end{aligned}
$$
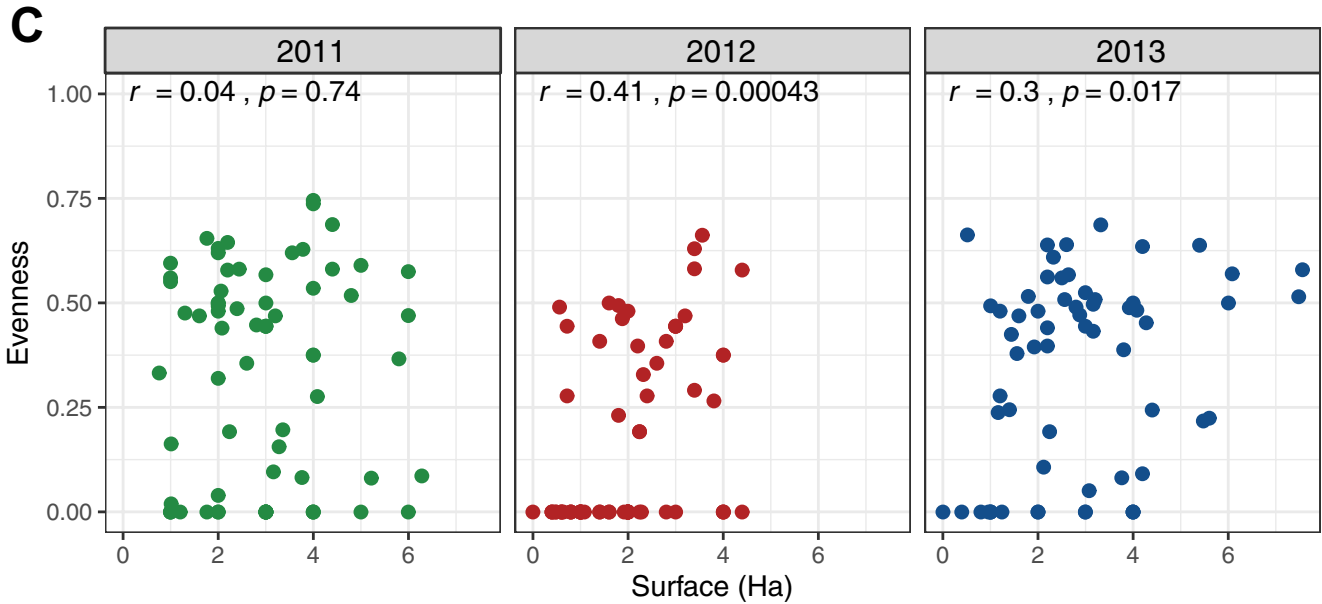

Year

- 2011

- 2012

- 2013

Fig. 2 Cultivated area and diversity estimates in 2011, 2012, and 2013. A Cultivated surface, richness, and evenness per farmer in 2011 (green filled symbols and boxes), 2012 (red filled symbols and boxes), and 2013 (blue filled symbols and boxes). Box plots represent first quartile, median and third quartile. Groups were compared by non-parametric Kruskal-Wallis test with Dunn's multiple comparisons tests. B, C Correlations between the cultivated surface and the biodiversity indexes richness $(\mathbf{B})$ and evenness $(\mathbf{C})$ using the nonparametric Spearman's rank test 


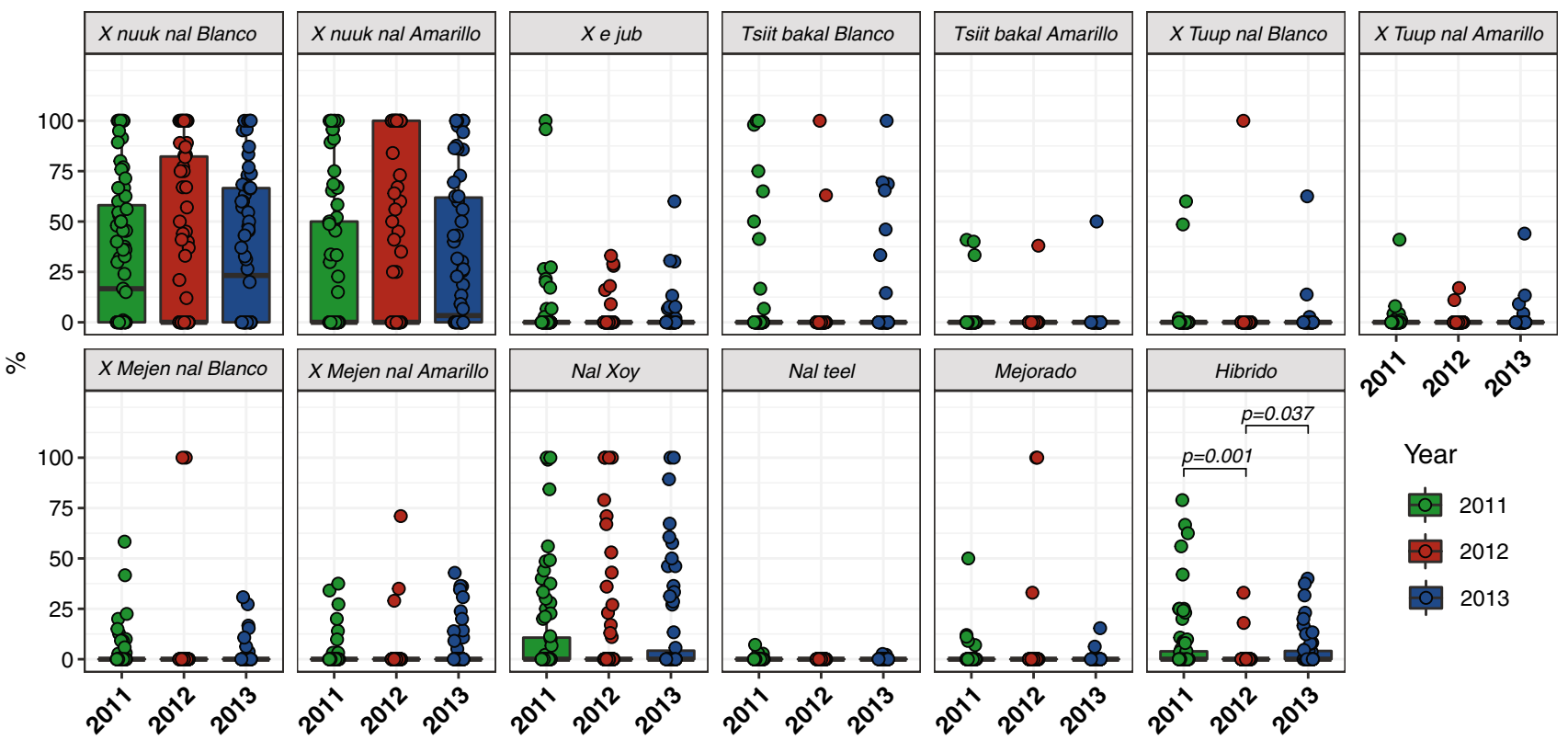

Fig. 3 Cultivated maize varieties in 2011, 2012, and 2013. Percentage of areas cultivated with the indicated maize varieties in 2011 (green filled symbols and boxes), 2012 (red filled symbols and boxes) and 2013 (blue filled symbols and boxes). Box plots represent first

that in 2011 only 18 farmers out of $71(25.3 \%)$ chose to sow only one variety. In 2012, most farmers (40 out of 68, $58.8 \%$ ) decided to plant only one variety. In 2013, farmers sowing only one variety were only 14 out of $62(22.6 \%)$. The majority $(21 / 40,52.5 \%)$ of farmers that in 2012 sowed just one variety chose to grow only their main $X$-nuuk nal variety or a different $X$-nuuk nal. Six farmers $(15 \%)$ who grew minor varieties in 2011 switched to $X$-nuuk nal varieties in 2012. Only two farmers (5\%) made the opposite decision and replaced their $X$-nuuk nal with a minor variety. Six farmers $(15 \%)$ kept growing minor varieties or chose Mejorado. Five farmers (12.5\%) kept growing only one variety over the 3 years. These results confirm that the main traditional maize $X$-nuuk nal retained a dominant position over the 3 years both in terms of surface area and diffusion among farmers, compared to minor varieties, which are less frequently grown and cultivated on smaller surfaces.

\section{Seed network}

In 2013, despite the reduction in the cultivated surface area observed in 2012, farmers were able to restore the maize diversity that they previously had in their fields. This ability suggests the existence of farmers' stock of seeds from past quartile, median and third quartile. Groups were compared by nonparametric Kruskal-Wallis test with Dunn's multiple comparisons tests. P-values are indicated when statistically significant differences between years exist

harvests ${ }^{6}$ and sources of seeds external to the household. After calculating each farmer's seed need and the amount of seed received in 2011, 2012, and 2013, we inferred the amount of seed that came from stored farmers' lots as the difference between the amount of seed needed and the amount received from external sources. Farmers mainly used the seeds they had stored from preceding years, and they were able to complete the amount of seed needed with seeds external to the household (Supplemental Fig. 3).

In 2012, a drastic reduction in seed transactions was observed compared to 2011 (Fig. 4A), with only three farmers receiving seeds and three others giving seeds in 2012, most likely as a consequence of the decrease in maize cultivated area and the subsequent reduced need for seeds during that year. We observed that the seed flow, both given and received, significantly increased from 2012 to 2013 (Fig. 4A). This increase is likely the consequence of the restoration of farmers' cultivated area in 2013 and the need for exogenous seeds to complete farmer seed lots. The reactivation of seed flows observed in 2013 compared to 2012 involved all levels, even leading to a slight increase in seeds exchanged at the family and community level compared to 2011 (Fig. 4B). Amounts of seeds given to other communities in 2013 returned to levels similar to those of 2011

\footnotetext{
${ }^{6}$ Maize seed can be saved and replanted for around 2 years with relatively little loss of germination capacity.
} 
A
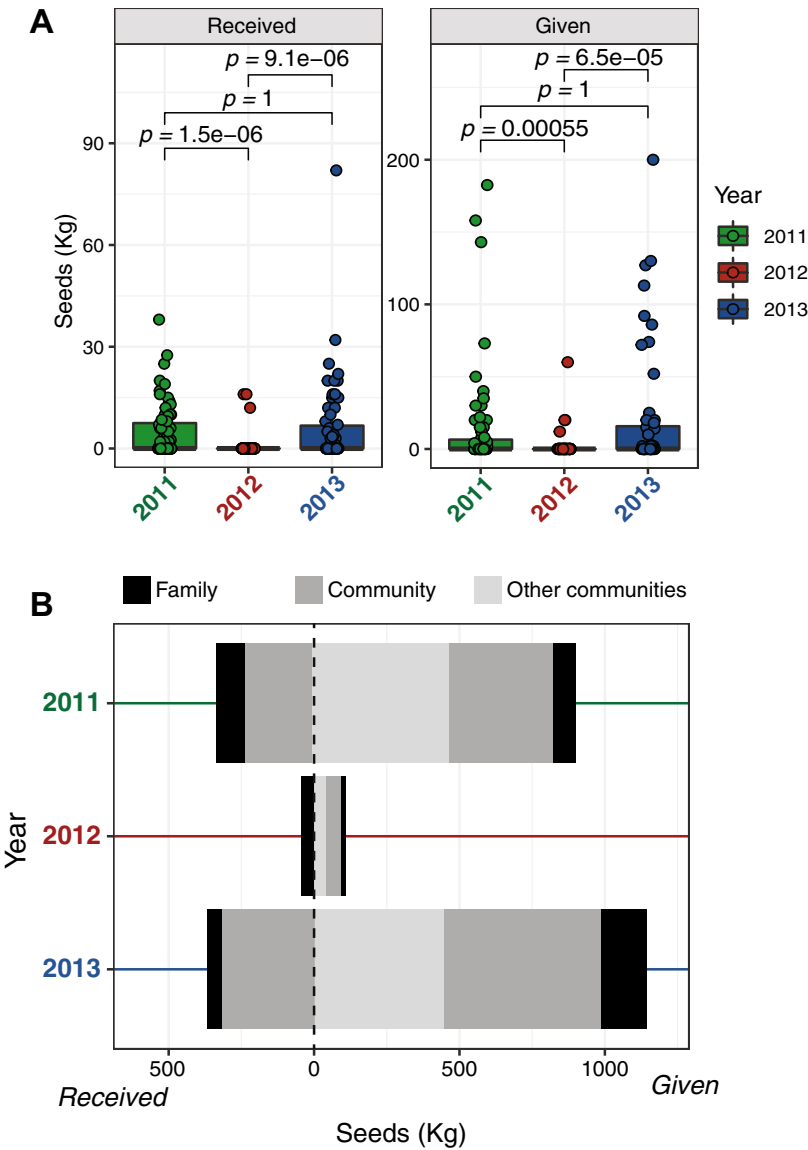

Fig. 4 Quantity of seeds received or given in 2011, 2012, and 2013. A Seeds received (left panel) or given (right panel) in 2011 (green filled symbols and boxes), 2012 (red filled symbols and boxes), and 2013 (blue filled symbols and boxes). Box plots represent first quartile, median and third quartile. Groups were compared by non-parametric Kruskal-Wallis test with Dunn's multiple comparisons tests. B Black-filled bars represent the proportion of seeds exchanged inside the family, gray-filled bars represent the proportion of seeds exchanged outside the family but inside the community, and light gray-filled bars represent the proportions of seeds exchanged outside the community

(Fig. 4B). The number of neighboring villages receiving seeds from Yaxcabá dropped from $2011(\mathrm{n}=8)$ to 2012 $(n=3)$, then increased again in $2013(n=8$; Fig. 5, upper panels). It should be noted that seed exchange relations with partners located in the smaller villages around Yaxcabá mostly took place in the "given" direction (Figs. 4B, $5)$. The only transaction which took place in the opposite direction occurred with a shop located in Merida for hybrid seeds (Fig. 5). This shows the central role of Yaxcabá village as a provider of seed stocks to smaller nearby communities.

Supplemental Table 1 summarizes the number and the direction of transactions, as well as the amount of seeds exchanged over the 3 years studied. Interestingly, the great majority of seeds exchanged were from landraces (mainly $X$-nuuk nal Blanco or Amarillo and Ts'iit-bakal Blanco) or the locally improved variety Nal-Xoy, followed by exchanges involving Mejorado or Híbrido (Fig. 6 and Supplemental Table 2).

Scholars have already pointed out that family bonds shape seed networks (Badstue et al. 2006), and that seed flow is mainly based on local networks (Perales et al. 2003a; Brush and Perales 2007). The seed search process seems to also be shaped by circumstances and social rules within the community. During the interviews, farmers explained that it would be very unlikely that people ask for seeds from a farmer who does not grow a milpa each season. Instead, they would ask "a los que son muy milperos" (those who are very devoted to the milpa). We found that most farmers are involved in the local seed network in Yaxcabá; however, there are presumably some leaders who are more active in providing seed. Supplemental Fig. 4 shows the contribution of givers during the 3 years. Two farmers ( 5 and 76 ) were present over the 3 years of the survey while one (88) was present in 2012 and 2013. Six other givers $(32,33,53,69,80,84)$ were present both in 2011 and in 2013 but not 2012.

Supplemental Fig. 5 shows the transactions among farmers inside Yaxcabá village and to neighboring villages in 2013. This analysis shows that transactions mainly happen on a farmer-to-farmer basis and sometimes in both directions (given and received) within the community while, as aforementioned (Fig. 5), the flow toward other communities was only in the "given" direction. Farmers seemed to have their preferences and ideas about which farmers can be a reliable source for seeds. When asked to provide us the names of farmers from whom, in case of need, they would request seeds, farmers provided twenty different names. Six of them appear among interviewed farmers that are givers in 2013 (Supplemental Fig. 5). Interestingly the two farmers who were always present as givers over the 3 years, were also among the farmers who were most often mentioned as ideal seed providers (farmer number 5 was cited 4 times and farmer 76 was cited 6 times; Supplemental Fig. 5). Interestingly, farmers who have an important role at the Yaxcabá level are also important as seed providers for the smaller communities outside Yaxcabá (Supplemental Fig. 5). We did not find patterns of characteristics distinguishing givers from receivers. In particular, we did not observe any statistically significant difference in the size of the milpa, richness or evenness between givers and receivers (Supplemental Fig. 6).

\section{Discussion}

In this work, we studied the dynamics of maize diversity and farmers' seed supply over 3 years, investigating farmers' choices in terms of varieties and factors influencing the nature and the amount of seed transactions. In 2012, 


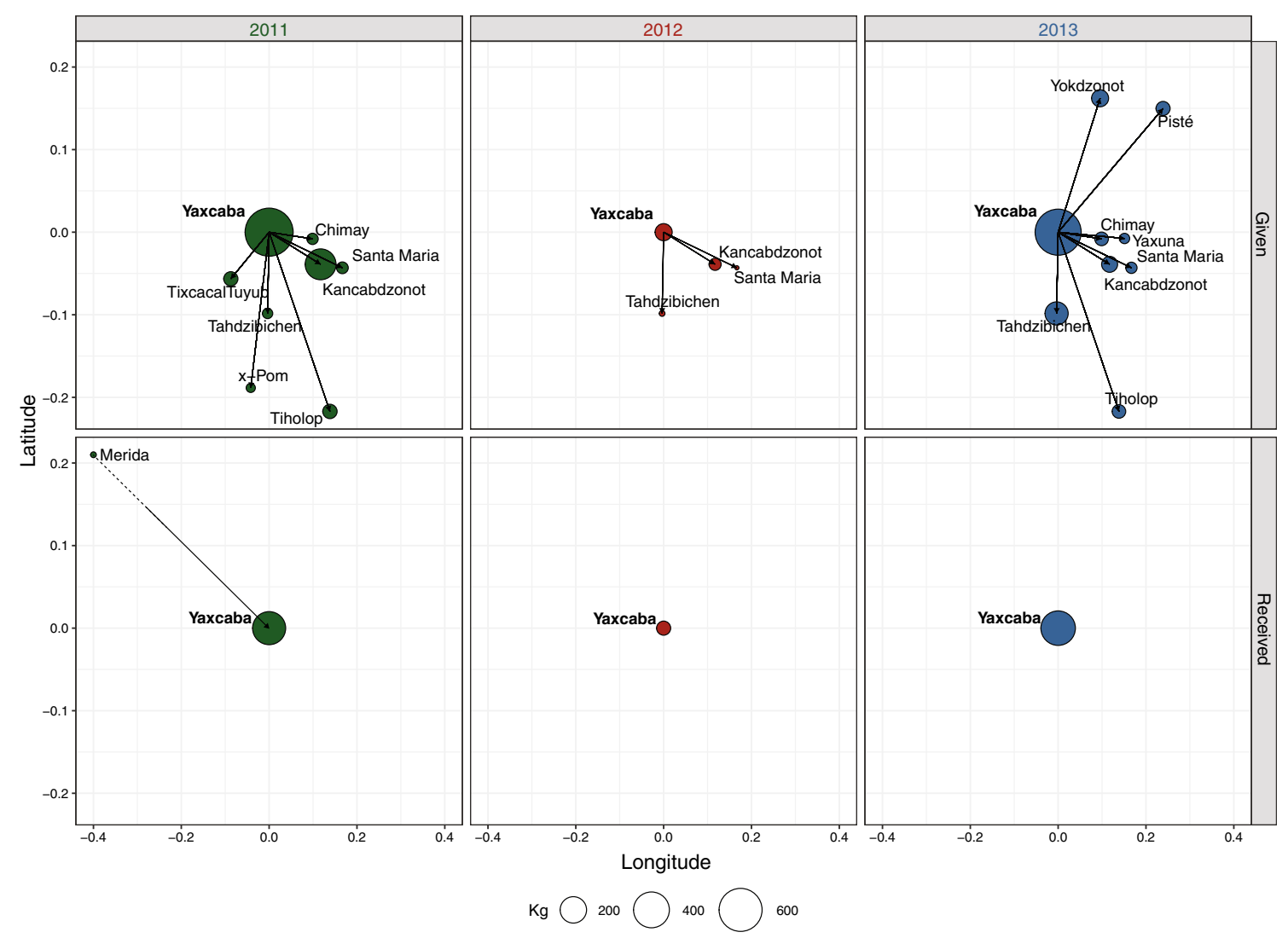

Fig. 5 Seed exchanges between Yaxcabá and surrounding communities. Representation of seed exchanges (given, upper panels, and received, lower panels) between Yaxcabá and indicated communities in 2011 (green), 2012 (red) and 2013 (blue). Nodes size is propor-

a critical climate event of excess precipitation allowed us to study in more detail some mechanisms at work shaping maize diversity and seed provision. We analyzed how this event affected the maize diversity sown, and the farmers' ability to recover and restore the diversity usually cultivated in the community. The effects of a critical climate event highlighted factors that can have a negative impact on crop diversity conservation. The first relates to the loss of land available for milpa cultivation, forcing farmers to reduce maize diversity in their milpa. The second factor concerns the possibility of shortages in seed supply in case extreme events were to recur over several years.

\section{Crop diversity and space limitation}

Studies on maize diversity in Mexico have shown that small farmers usually devote most of their land to only one maize variety (Perales 1998). Although germplasm banks in Mexico have reported 21 maize races from Chiapas (Perales and Hernández-Casillas 2005) in the latest field collection from this state, only three races represented more than $80 \%$ of the collected seed lots (Brush and Perales 2007). Even in areas tional to the weight of exchanged seeds as indicated in the figure. The direction of the arrows indicates the direction of the flow. The fact that Merida is located further from Yaxcabá than shown in the scale $(108 \mathrm{~km})$ is represented by the dashed line

where most farmers grow more than one maize population in their plots, there is usually a dominant population, showing that maize diversity is constituted by major and minor varieties (Perales et al. 2003a, b). In some areas of Oaxaca state, most of the land planted with maize is occupied by whitekernel maize, and varieties of other colors are grown on smaller surfaces (Lazos Chavero 2008, 2013). In Yaxcabá, we found the X-nuuk nal Blanco and Amarillo varieties are dominating the landscape followed by the locally improved variety Nal-Xoy. In 2012, a year of reduced cultivated area due to the high rainfall, most of the farmers chose to focus on only one variety, renouncing to the more diverse array of maize that they usually sowed (Supplemental Fig. 2).

Most of the transactions over the 3 years involve long cycle local varieties such as $X$-nuuk nal, while minor varieties, even those with special characteristics appreciated by farmers, like the blue-kernel $X-e$-jub, seem less frequently exchanged among farmers (Fig. 6). Our data indicate that in 2012, when less area to plant was available, farmers decided to concentrate their efforts on what they know best and consider as more reliable among landraces (Fig. 3; Supplemental Fig. 2). They explained that X-nuuk 

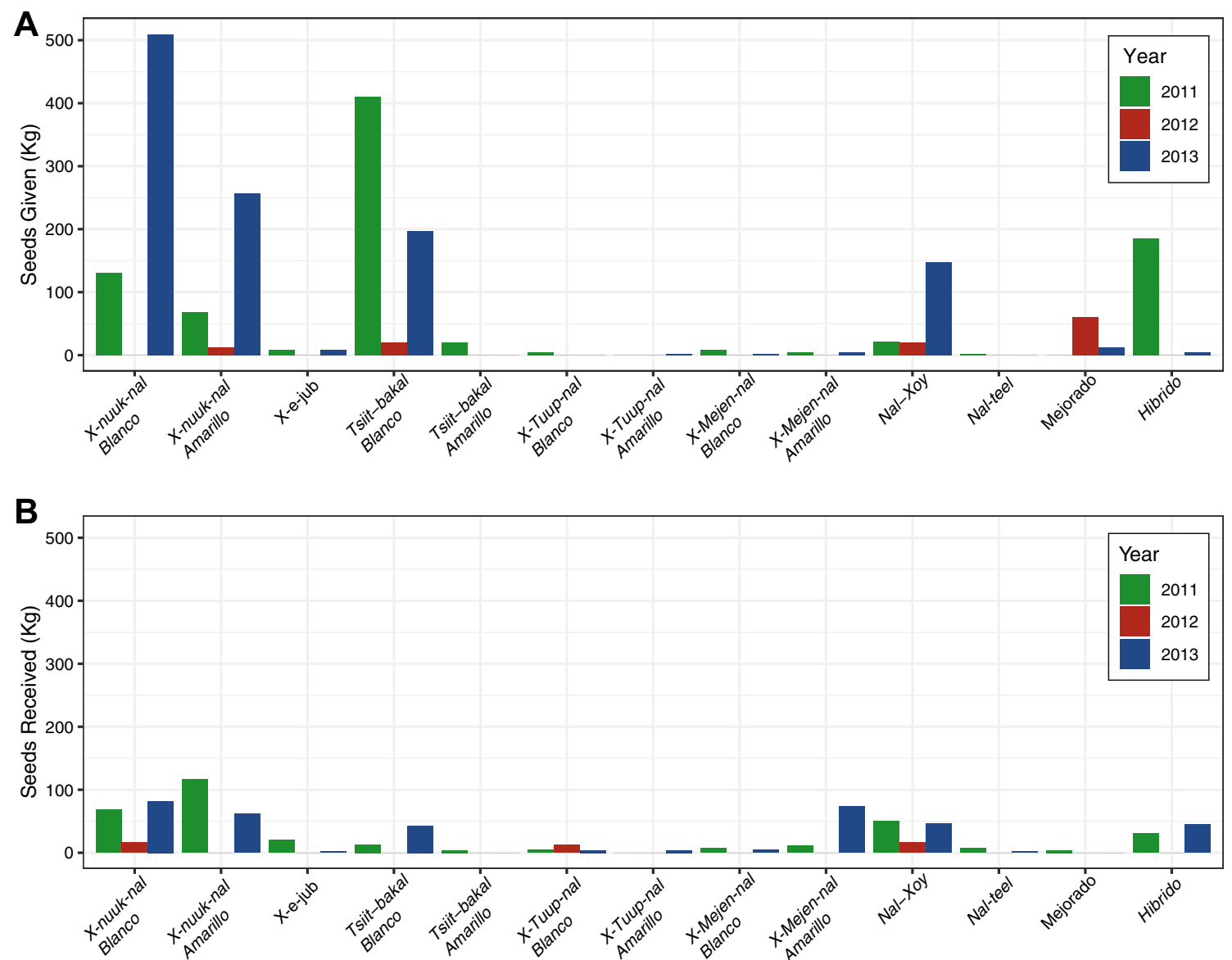

Fig. 6 Seed exchanges of different maize varieties in 2011, 2012 and 2013. Total amount of kilograms of given (A) or received (B) seeds of the indicated maize varieties in 2011 (green filled bars), 2012 (red filled bars) and 2013 (blue filled bars)

nal is steadier under variation in rain regimes. In 2012 farmers renounced planting hybrids (Fig. 3) which, along with some other minor varieties, are described by farmers as "needy varieties" (que necesitan más cuidado) which farmers seem to turn down in more difficult years. Based on our findings, two non-mutually exclusive maize dynamics can increase under climate change: (1) minor varieties would be less cultivated; (2) farmers are not replacing their local maize with hybrids and instead privilege dominant landraces. If minor landraces come to occupy less and less space, shrinking their population size, they will become less effective in terms of evolution and this can influence how well populations will be able to respond to selection and climate stress (Perales et al. 2003a). The dynamic of minor varieties and the problem of their population size should be better investigated in the future from a population genetics point of view.

Adding more species or mixing genotypes of the same crop in farmers' fields has been reported as a strategy employed by farmers to combine and enhance agroecosystem functioning and avoid risks (Jackson et al. 2007;
Di Falco and Perrings 2005). Our findings show that farmers pursued a strategy of risk avoidance focusing on most reliable varieties, thus narrowing diversity. However, this choice does not actually contradict the above-mentioned body of knowledge. We show that after a critical event affecting farmers' agricultural practices, farmers simplified their milpas, but they considered the reduction in the number of cultured varieties as a temporary decision and counted on the diversity present at the community level to restore their individual on-farm diversity. This study found that farmers restored as soon as possible their formerly cultivated diversity, suggesting that they rely on that diversity and want to conserve it when possible. Temporarily reducing the array of maize diversity on-farm may be considered as part of an overall strategy where crop diversity can be increased or reduced, according to specific farmer needs and climate conditions. Understanding fluctuations, weaknesses, and the restorative potential of the current local provision of seeds is extremely important for designing management strategies to support biodiversitybased agriculture. 


\section{Seed diversity network between resilience and threats}

The intensity of maize seed transactions varies substantially across regions of Mexico according to altitudinal transects, ethnic groups, and kinds of seeds (Perales 1998; van Etten and de Bruin 2007; Dyer and López-Feldman 2013). To our knowledge only Badstue et al. $(2006,2007)$ have described more than 1 year of seed flows. In Yaxcabá, we found deep fluctuations in seed flow over the years, showing that important variations occur in the same community and not only across regions.

Farmers create local maize seed sales or exchange channels, which play a pivotal role in maintaining the genetic diversity of these species (Perales et al. 2003a, b; Brush and Perales 2007; Bellon and Hellin 2011; Lazos and Chauvet 2011). When farmers don't have to deal with extreme climate events, the search for seeds in Yaxcabá can be explained as reported in other Mexican communities and in other countries by the wish to experiment with new varieties (Badstue et al. 2006, 2007), to improve their varieties, and by the desire to complete their seed lots (Almekinders et al. 1994; Louette et al. 1997; van Etten and de Bruin 2007). For example, during informal discussions, farmers claimed that when the growing cycle of their variety becomes longer (time to maturation) or the plants become taller, they integrate better seeds from an external source. Despite the fact that improved varieties are available and can be acquired from markets, most farmers continued to prefer local varieties over hybrids, especially during critical times such as 2012 when the surface reduction forced them to choose among varieties (Fig. 3, Supplemental Fig. 2). Even if farmers' method of seed management is not usually considered as a cause for concern (Louette et al. 1997), there are factors that can explain why some farmers are more likely givers than others. Analyzing seed exchanges, we observed that some farmers played a more important role than others as seed givers (Supplemental Figs. 4 and 5). Trust in seed sources can play an important role in farmers' decisions (Badstue et al. 2006, 2007). According to farmers, someone who is recognized as "muy milpero" can be a "trusted" provider because their seeds are probably carefully selected, conserved, and coming from the last harvest. We can also hypothesize that trusted givers are more likely to have enough seeds to give to others after having satisfied their own seed needs. Since there are no significant differences in the maize-cultivated surface area between givers and receivers, this is probably the result of a different family usage of maize that leads to a surplus.

With the renewed dynamics of exchange and sale of seeds in 2013, farmers in Yaxcabá were able to complete their desired amount of seeds (Supplemental Fig. 3) and also to reintroduce into their milpas the maize diversity of the previous years (Fig. 2). In 2013, diversity was restored through a kind of "community resilience": despite the reduction of the number of farmers cultivating each variety in 2012 (Fig. 2), all varieties were preserved within the community (Fig. 3). This result demonstrates the importance of conservation at the community level.

In Mexico, conservation of maize diversity is a "social event". Farmers are not worried about the loss of their maize seeds because they usually consider that it will be easy to find them from neighbors (Perales 1998: 286). In Yaxcabá, the local maize seed supply is considered reliable, and farmers report they can find what they need for a good price and quality. In Mexico, farmer-to-farmer seed transactions are mostly based on social relations and seed lots are obtained mostly within the community (Louette et al. 1997; Perales et al. 2003a, b; Perales et al. 2005; van Etten and de Bruin 2007) or, when transactions occur externally, usually they take place within $10 \mathrm{~km}$ from the community (Bellon et al. 2011). Currently, the local seed network for maize in Yaxcabá does not appear to suffer major limitations, but future changes in maize production systems combined with climate change may alter it. For example, a constant drop in the number of maize farmers, due to aging, retirement or migration, could limit the resilience of the current system. Given that seed networks are mostly circumscribed within the village, if critical climatic events occur consecutively or too frequently, and break the capability of many individual farmers to conserve their seeds, seed network resilience inside the community could be seriously impacted. Our findings raise several questions that should be addressed further: How many bad years can pass without affecting the ability of farmers to maintain their varietal diversity and seed network? If this happens, which kind of adjustments in the local seed supply system could help farmers to recover the lost diversity? Is there a limit or critical amount of reduction in the sown area that, if crossed, will affect the diversity present in the community?

Our results indicate that expanding the possibilities for farmers to find seeds that they need outside their community will be a fundamental part of the design of climateadaptation strategies in agriculture. As already suggested by Mercer and Perales (2010), Jarvis et al. (2011) and Hellin et al. (2014), the idea is to strengthen the emergence of institutionally sustained, diverse seed systems that respect and support farmers' preferences, including for landraces. In the Yucatán peninsula, a region very often affected by periodic drought and extreme climatic events, developing local actions focusing on seed networks will be a key element of local adaptation strategies. Over the last decade, some initiatives have emerged: the ferias de semillas (seed fairs) organized through collaborations between local associations, research institutions and universities, 
raised interest among farmers and students. ${ }^{7}$ Farmers are seeing these initiatives as excellent opportunities to socialize and to find rare seeds, but they do not rely upon these scattered events for their primary seed needs, which are still dependent on their community network. These initiatives, building awareness about seed diversity and conservation, are extremely important, and they should be supported and implemented as part of a diversified system able to support farmers in their seed needs.

\section{Conclusions}

During a 3-year study on maize crop diversity management, we encountered a critical climate event that revealed patterns underlying seed networks possibly limiting the resilience of local seed systems. We analyzed the impact of a heavy precipitation event in April 2012, which limited the ability of farmers to prepare their plots and sow the array of maize varieties that they usually grow. Identifying farmers' choices about what varieties to sow in a time of crisis, we found that farmers focused more on maize landraces and locally improved or locally adapted varieties and turned away from hybrids. We showed that a diversified maize landscape can be maintained at the community level and restored, even after a critical event, thanks to farmers' saved seeds and seed flow. This event allowed us to spotlight the crucial role of community seed conservation on which maize diversity relies. At the same time, it also made clear the issues and challenges that a community seed system may confront in a climate change era. It is urgent to investigate further the relationship between climate change and seed flows to predict future dynamics in conservation, particularly related to increased unpredictability of rainfall amount and patterns. This need calls, once again, for the integration of farmers in seed provision policies and strategies, as well as in conservation and breeding programs. Adaptive solutions led by farmers, geneticists, and biologists as well as social scientists and associations, are essential to monitoring and sustaining local seed systems. The challenge is to assure the conservation of crop genetic diversity through strengthening the connectivity between different seed sources, communities, and storage facilities. This includes developing a long-term perspective for institutions and local actors that guarantees the availability of seeds linking local seed networks, participatory

\footnotetext{
7 Among the associations see: Misioneros A. C Guardianes de semillas, Indignación, Escuela de agricultura ecológica U Yits Ka'an, Educe. Events are often posted on newspapers and associations' websites https://www.prensaindigena.org/web/index.php?option=com content \&view=article \&id=12389: mexico-ferias-de-semillas-del-surde-Yucatán\&catid=86:noticias.
}

crop improvement, and information systems to support the availability of diverse seeds.

Supplementary Information The online version contains supplementary material available at https://doi.org/10.1007/s10460-021-10249-3.

Acknowledgements Marianna Fenzi was supported by a École des Hautes Etudes en Sciences Sociales Ph.D. scholarship and a Future Food Initiative Fellowship. The authors thank the Swiss Agency for Development and Cooperation (SDC) for providing complementary financial support to this study. They thank the Comision Nacional del Agua (CONAGUA) for providing rainfall data. They especially thank all farmers involved in this study. The authors would like to express their most sincere gratitude to Dr. Luis Manuel Arias Reyes for his guidance and friendship. We dedicate this study to his memory.

Funding Open Access funding provided by EPFL Lausanne.

Open Access This article is licensed under a Creative Commons Attribution 4.0 International License, which permits use, sharing, adaptation, distribution and reproduction in any medium or format, as long as you give appropriate credit to the original author(s) and the source, provide a link to the Creative Commons licence, and indicate if changes were made. The images or other third party material in this article are included in the article's Creative Commons licence, unless indicated otherwise in a credit line to the material. If material is not included in the article's Creative Commons licence and your intended use is not permitted by statutory regulation or exceeds the permitted use, you will need to obtain permission directly from the copyright holder. To view a copy of this licence, visit http://creativecommons.org/licenses/by/4.0/.

\section{References}

Abidoye, B.O., P. Kurukulasuriya, and R. Mendelsohn. 2017. Southeast asian farmer perceptions of climate change. Climate Change Economics 08: 1740006. https://doi.org/10.1142/S201000781 7400061.

Almekinders, C.J.M., and N.P. Louwaars. 1999. Farmers' seed production: New approaches and practices. Rugby: Intermediate Technology.

Almekinders, C.J.M., N.P. Louwaars, and G.H. De Bruijn. 1994. Local seed systems and their importance for an improved seed supply in developing countries. Euphytica 78: 207-216. https://doi.org/ 10.1007/BF00027519.

Altieri, M.A. 2002. Agroecology: The science of natural resource management for poor farmers in marginal environments. Agriculture, Ecosystems \& Environment 93: 1-24. https://doi.org/10.1016/ S0167-8809(02)00085-3.

Altieri, M.A., and C.I. Nicholls. 2017. The adaptation and mitigation potential of traditional agriculture in a changing climate. Climatic Change 140: 33-45. https://doi.org/10.1007/s10584-013-0909-y.

Aquino, P., F. Carrión, R. Calvo, and D. Flores. 2001. Selected maize statistics in Pingali, P.L. "CIMMYT 1999/2000 World maize facts and trends. Meeting world maize needs: Technological opportunities and priorities for the public sector." Mexico, D.F., CIMMYT.

Arias Reyes, L.M., D.I. Jarvis, D. Williams, L. Latournerie, M.F. Castillo, F. Márquez, P. Ramírez, R. Ortega, J. Ortiz, E. Sauri, J. Duch, and V. Cob. 2004. Conservación in situ de la biodiversidad de las variedades locales en la milpa de Yucatán, MéxicoManejo de la diversidad de los cultivos en los agroecosistemas tradicionales. Vol. Manejo de la diversidad de los cultivos en los 
agroecosistemas tradicionales. Instituto Internacional de Recursos Fitogenéticos, Cali, Colombia: Bioversity International.

Astier, M., Q. Orozco-Ramírez, R. Walker, Y. Galván-Miyoshi, C. González-Esquivel, and C.S. Simmons. 2020. Post-NAFTA changes in peasant land use-The case of the Pátzcuaro Lake watershed region in the Central-West México. Land 9 (3): 75.

Badstue, L.B., M.R. Bellon, J. Berthaud, X. Juárez, M. Rosas, A.M. Solano, and A. Ramírez. 2006. Examining the role of collective action in an informal seed system: A case study from the central valleys of Oaxaca, Mexico. Human Ecology 34: 249-273. https:// doi.org/10.1007/s10745-006-9016-2.

Badstue, L.B., M.R. Bellon, J. Berthaud, A. Ramírez, D. Flores, and X. Juárez. 2007. The dynamics of farmers' maize seed supply practices in the central valleys of Oaxaca, Mexico. World Development 35: 1579-1593. https://doi.org/10.1016/j.worlddev.2006. 05.023 .

Badstue, L.B., M.R. Bellon, J. Berthaud, A. Ramirez, D. Flores, X. Juarez, and F. Ramirez. 2005. Collective action for the conservation of on-farm genetic diversity in a center of crop diversity: An assessment of the role of traditional farmers' networks. AgEcon Search. https://doi.org/10.22004/ag.econ.50067.

Bellon, M.R. 1991. The ethnoecology of maize variety management: A case study from Mexico. Human Ecology 19: 389-418.

Bellon, M.R. 2004. Conceptualizing interventions to support on-farm genetic resource conservation. World Development 32: 159-172. https://doi.org/10.1016/j.worlddev.2003.04.007.

Bellon, M.R., and J. Berthaud. 2006. Traditional Mexican agricultural systems and the potential impacts of transgenic varieties on maize diversity. Agriculture and Human Values 23: 3-14. https://doi.org/10.1007/s10460-004-5861-z.

Bellon, M.R., and S.B. Brush. 1994. Keepers of maize in Chiapas, Mexico. Economic Botany 48: 196-209.

Bellon, M.R., and J. Hellin. 2011. Planting hybrids, keeping landraces: Agricultural modernization and tradition among small-scale maize farmers in Chiapas, Mexico. World Development 39: 1434-1443.

Bellon, M.R., D. Hodson, D. Bergvinson, D. Beck, E. MartinezRomero, and Y. Montoya. 2005. Targeting agricultural research to benefit poor farmers: Relating poverty mapping to maize environments in Mexico. Food Policy 30: 476-492.

Bellon, M.R., D. Hodson, and J. Hellin. 2011. Assessing the vulnerability of traditional maize seed systems in Mexico to climate change. Proceedings of the National Academy of Sciences 108: 13432-13437. https://doi.org/10.1073/pnas.1103373108.

Bellon, M.R., A. Mastretta-Yanes, A. Ponce-Mendoza, D. Ortiz-Santamaría, O. Oliveros-Galindo, H. Perales, F. Acevedo, and J. Sarukhán. 2018. Evolutionary and food supply implications of ongoing maize domestication by Mexican campesinos. Proceedings of the Royal Society B: Biological Sciences 285: 20181049. https://doi.org/10.1098/rspb.2018.1049.

Bellon, M.R., and J. Risopoulos. 2001. Small-scale farmers expand the benefits of improved maize germplasm: A case study from Chiapas, Mexico. World Development 29: 799-811.

Bellon, M.R., and E.J. Taylor. 1993. "Folk" soil taxonomy and the partial adoption of new seed varieties. Economic Development and Cultural Change 41: 763-786.

Bellon, M.R., and J. Van Etten. 2014. Climate change and on-farm conservation of crop landraces in centres of diversity. In Plant genetic resources and climate change, 137-150. Wallingford: $\mathrm{CAB}$ International.

Brush, S.B. 1995. In situ conservation of landraces in centers of crop diversity. Crop Science. https://doi.org/10.2135/cropsci1995. 0011183X003500020009x.

Brush, S.B., M.B. Bellon, R.J. Hijmans, Q. Orozco Ramirez, H.R. Perales, and J. Van Etten. 2015. Assessing maize genetic erosion. Proceedings of the National Academy of Sciences 112: E1-E1.
Brush, S.B., and H.R. Perales. 2007. A maize landscape: Ethnicity and agro-biodiversity in Chiapas Mexico. Agriculture, Ecosystems \& Environment 121: 211-221.

Ceccarelli, S., S. Grando, M. Maatougui, M. Michael, M. Slash, R. Haghparast, M. Rahmanian, et al. 2010. Plant breeding and climate changes. The Journal of Agricultural Science 148: 627-637. https://doi.org/10.1017/S0021859610000651.

CEDRSSA. 2018. Uso de semillas mejoradas en México. http://www. cedrssa.gob.mx/post_uso_de_-n-semillas_mejoradas-n-_en_ mn-xico.htm.

Chávez-Servia, J.L., L.M. Arias-Reyes, D.I. Jarvis, J. Tuxhill, D. LopeAlzina, and C. Eyzaguirre. 2002. Managing crop diversity in traditional agroecosystems. Abstracts, Merida, Mexico, 13-16 February 2002. Managing crop diversity in traditional agroecosystems. Abstracts, Merida, Mexico, 13-16 February 2002. International Plant Genetic Resources Institute (IPGRI).

Cleveland, D.A., and D. Soleri. 2007. Extending Darwin's analogy: Bridging differences in concepts of selection between farmers, biologists, and plant breeders. Economic Botany 61: 121. https:// doi.org/10.1663/0013-0001(2007)61[121:EDABDI]2.0.CO;2.

Conde, C., R. Ferrer, and S. Orozco. 2006. Climate change and climate variability impacts on rainfed agricultural activities and possible adaptation measures. A Mexican case study. Atmósfera 19: 181-194.

Coomes, O.T., S.J. McGuire, E. Garine, S. Caillon, D. McKey, E. Demeulenaere, D.I. Jarvis, et al. 2015. Farmer seed networks make a limited contribution to agriculture? Four common misconceptions. Food Policy 56: 41-50. https://doi.org/10.1016/j. foodpol.2015.07.008.

Di Falco, S., and C. Perrings. 2005. Crop biodiversity, risk management and the implications of agricultural assistance. Ecological Economics 55 (4): 459-466.

Doebley, J. 2004. The genetics of maize evolution. Annual Review of Genetics 38: 37-59.

Donnet, L., D. López, J. Arista, F. Carrión, V. Hernández, and A. González. 2012. El potencial de mercado de semillas mejoradas de maíz en México. Mexico City: CIMMYT.

Dyer, G.A., and A. López-Feldman. 2013. Inexplicable or simply unexplained? The Management of Maize Seed in Mexico. Edited by Randall P. Niedz. PLoS ONE 8: e68320. https://doi.org/10.1371/ journal.pone.0068320.

Dyer, G.A., A. López-Feldman, A. Yúnez-Naude, and J.E. Taylor. 2014. Genetic erosion in maize's center of origin. Proceedings of the National Academy of Sciences 111: 14094-14099.

Dyer, G.A., and J.E. Taylor. 2008. A crop population perspective on maize seed systems in Mexico. Proceedings of the National Academy of Sciences 105: 470-475. https://doi.org/10.1073/ pnas.0706321105.

Dzib Aguilar, L.A., R. Ortega Paczka, and J.C. Segura-Correa. 2016. In situ conservation and participative improvement of creole maize in the peninsula de Yucatán. Tropical and Subtropical Agroecosystems 19: 51-59.

Eakin, H. 2005. Institutional change, climate risk, and rural vulnerability: Cases from Central Mexico. World Development 33: 1923-1938. https://doi.org/10.1016/j.worlddev.2005.06.005.

Eakin, H. 2006. Weathering risk in rural Mexico: Climatic, institutional, and economic change. Tucson: University of Arizona Press.

Eakin, H., H.R. Perales, K. Appendini, and S. Sweeney. 2014. Selling maize in Mexico: The persistence of peasant farming in an era of global markets. Development and Change 45: 133-155. https:// doi.org/10.1111/dech. 12074 .

Easterling, D.R., J. Arnold, T. Knutson, K. Kunkel, A. LeGrande, L.R., Leung, R. Vose, D. Waliser, and M. Wehner. 2017. Chapter 7: Precipitation change in the United States. In Climate science special report: A sustained assessment activity of the U.S. Global 
change research program ed. Wuebbles, D.J., et al., 301-335. Washington, DC: U.S. Global Change Research Program. https:// doi.org/10.7930/J0H993CC.

Ewell, P.T., and D. Merrill-Sands. 1987. Milpa in Yucatán: A longfallow maize system and its alternatives in the Maya peasant economy. Comparative Farming Systems 1987: 95-129.

Fedoroff, N.V. 2003. Prehistoric GM corn. Science 302: 1158-1159. https://doi.org/10.1126/science.1092042.

Fenzi, M., D.I. Jarvis, L.E. Arias Reyes, L. Latournerie Moreno, and J. Tuxill. 2017. Longitudinal analysis of maize diversity in Yucatán, Mexico: Influence of agro-ecological factors on landraces conservation and modern variety introduction. Plant Genetic Resources 15: 51-63.

Fitting, E. 2006. The political uses of culture: Maize production and the GM corn debates in Mexico. Focaal 2006: 17-34.

Food and Agriculture Organization of the United Nations. 2019. The state of the world's biodiversity for food and agriculture. Edited by Julie Bélanger and Dafydd Pilling, Rome, Italy.

Halewood, M., I. Lopez Noriega, and S. Louafi. 2012. Crop genetic resources as a global commons: Challenges in international law and governance. London: Routledge.

Hellin, J., M.R. Bellon, and S.J. Hearne. 2014. Maize landraces and adaptation to climate change in Mexico. Journal of Crop Improvement 28: 484-501. https://doi.org/10.1080/15427528. 2014.921800 .

Hodgkin, T., R. Rana, J. Tuxill, D. Balma, A. Subedi, I. Mar, D. Karamura, et al. 2007. Seed systems and crop genetic diversity in agroecosystems. Managing Biodiversity in Agricultural Ecosystems. https://doi.org/10.7312/jarv13648-006.

INEGI. 2009. Resultados del VIII Censo Agrícola, Ganadero y Forestal. Comunicado núm. 088/09, Aguascalientes, Ags.

Jackson, M., B. Ford-Lloyd, and M. Parry. 2013. Plant genetic resources and climate change. Wallingford: CABI.

Jackson, L.E., U. Pascual, and T. Hodgkin. 2007. Utilizing and conserving agrobiodiversity in agricultural landscapes. Agriculture, Ecosystems \& Environment 121 (3): 196-210.

Jarvis, D.I. 2005. Seed systems and crop genetic diversity on-farm: proceedings of a workshop, 16-20 September 2003, Pucallpa, Peru. Bioversity International, 2005.

Jarvis, D.I., A.H.D. Brown, P. Hung Cuong, L. Collado-Panduro, L. Latournerie-Moreno, S. Gyawali, T. Tanto, et al. 2008. A global perspective of the richness and evenness of traditional crop-variety diversity maintained by farming communities. Proceedings of the National Academy of Sciences 105: 53265331. https://doi.org/10.1073/pnas.0800607105.

Jarvis, D.I., T. Hodgkin, B.R. Sthapit, C. Fadda, and I. LopezNoriega. 2011. An heuristic framework for identifying multiple ways of supporting the conservation and use of traditional crop varieties within the agricultural production system. Critical Reviews in Plant Sciences 30: 125-176. https://doi.org/10. 1080/07352689.2011.554358.

Jarvis, D.I., C. Padoch, and H.D. Cooper. 2007. Managing biodiversity in agricultural ecosystems. New York: Columbia University Press.

Kato, T.A., C. Mapes, L. Ma Mera, J.A. Serratos, and R.A. Bye. 2009. Origen y diversificación del maíz: una revisión analítica. Universidad Nacional Autónoma de México, Comisión Nacional para el Conocimiento y Uso de la Biodiversidad. México, DF 116.

Keleman, A., J. Hellin, and D. Flores. 2013. Diverse varieties and diverse markets: Scale-related maize "profitability crossover" in the Central Mexican Highlands. Human Ecology 41: 683-705.

Lane, A., and A. Jarvis. 2007. Changes in climate will modify the geography of crop suitability: Agricultural biodiversity can help with adaptation. International Crops Research Institute for the
Semi-Arid Tropics (ICRISAT). December 2007. Volume 4, Issue

Lazos Chavero, E. 2008. La fragilidad de la biodiversidad: Semillas y suelos entre una conservación y un desarrollo empobrecido. In Seefoó Luján L. Desde los colores del maíz. Una agenda para el campo mexicano (2 vols.) El Colegio de Michoacán.

Lazos Chavero, E. 2013. In Resistencias de las sociedades campesinas? Control sobre la agrodiversidad y la riqueza genética de sus maíces?, Ed. del Consejo Nacional para la Cultura y las Artes. Fondo de Cultura Económica, México D.F, El Campesinado y su persistencia en la actualidad mexicana, 391427. Padilla T. Ed.

Lazos, E., and M. Chauvet. 2011. Análisis del contexto social y biocultural de las colectas de maíces nativos en México. Proyecto Global de Maíces, Informe de Gestión, CONABIO.

Lerner, A.M., and K. Appendini. 2011. Dimensions of peri-urban maize production in the Toluca-Atlacomulco Valley, Mexico. Journal of Latin American Geography 10: 87-106.

Lobell, D.B., B.B. Marshall, C. Tebaldi, M.D. Mastrandrea, W.P. Falcon, and R.L. Naylor. 2008. Prioritizing climate change adaptation needs for food security in 2030. Science 319: 607-610. https://doi.org/10.1126/science.1152339.

Lobell, D.B., W. Schlenker, and J. Costa-Roberts. 2011. Climate trends and global crop production since 1980. Science 333: 616-620. https://doi.org/10.1126/science.1204531.

López-Noriega, I., G. Galluzzi, M. Halewood, R. Vernooy, E. Bertacchini, D. Gauchan, and E. Welch. 2012. Flows under stress: Availability of plant genetic resources in times of climate and policy change. Working Paper No. 18 CGIAR Research Program on Climate Change, Agriculture and Food Security (CCAFS).

Louette, D., A. Charrier, and J. Berthaud. 1997. In situ conservation of maize in Mexico: Genetic diversity and maize seed management in a traditional community. Economic Botany 51: 20-38. https:// doi.org/10.1007/BF02910401.

Louette, D., and M. Smale. 2000. Farmers' seed selection practices and traditional maize varieties in Cuzalapa, Mexico. Euphytica 113: 25-41. https://doi.org/10.1023/A:1003941615886.

Magurran, A.E. 2013. Measuring biological diversity. New York: Wiley.

Maxted, N., L. Guarino, L. Myer, and E.A. Chiwona. 2002. Towards a methodology for on-farm conservation of plant genetic resources. Genetic Resources and Crop Evolution 49: 31-46. https://doi. org/10.1023/A:1013896401710.

McGuire, S., and L. Sperling. 2016. Seed systems smallholder farmers use. Food Security 8: 179-195. https://doi.org/10.1007/ s12571-015-0528-8.

McLean-Rodríguez, F.D., T.C.C. Villa, C.J.M. Almekinders, M.E. Pè, M. Dell'Acqua, and D. Costich. 2019. The abandonment of maize landraces over the last 50 years in Morelos, Mexico: A tracing study using a multi-level perspective. Agriculture and Human Values 36: 651-668. https://doi.org/10.1007/ s10460-019-09932-3.

Mercer, K.L. 2012. Climate change and the transgenic adaptation strategy: Smallholder livelihoods, climate justice, and maize landraces in Mexico. Global Environmental Change 22: 495-504.

Mercer, K.L., and H.R. Perales. 2010. Evolutionary response of landraces to climate change in centers of crop diversity. Evolutionary Applications 3: 480-493. https://doi.org/10.1111/j.17524571.2010.00137.x.

Mijatović, D., F. Van Oudenhoven, P. Eyzaguirre, and T. Hodgkin. 2013. The role of agricultural biodiversity in strengthening resilience to climate change: Towards an analytical framework. International Journal of Agricultural Sustainability 11: 95-107.

Moreno, L.L., J. Tuxill, E. Yupit Moo, L.M. Arias Reyes, J. Cristobal Alejo, and D.I. Jarvis. 2006. Traditional maize storage methods of Mayan farmers in Yucatan, Mexico: Implications for seed 
selection and crop diversity. Biodiversity \& Conservation 15 (5): 1771-1795.

Morris, M.L., J. Risopoulos, and D. Beck. 1999. Genetic change in farmer-recycled maize seed: A review of the evidence. Economics Working Paper 99-07. CIMMYT: 69.

Morton, J.F. 2007. The impact of climate change on smallholder and subsistence agriculture. Proceedings of the National Academy of Sciences 104: 19680-19685. https://doi.org/10.1073/pnas. 0701855104.

Mutekwa, V.T. 2009. Climate change impacts and adaptation in the agricultural sector: The case of smallholder farmers in Zimbabwe. Journal of Sustainable Development in Africa 11: 20.

Naylor, R., D.S. Battisti, D.J. Vimont, W.P. Falcon, and M.B. Burke. 2007. Assessing risks of climate variability and climate change for Indonesian rice agriculture. Proceedings of the National Academy of Sciences 104: 7752-7757. https://doi.org/10.1073/ pnas.0701825104.

Olesen, J.E., M. Trnka, K. Kersebaum, A.O. Skjelvåg, B. Seguin, P. Peltonen-Sainio, F. Rossi, J. Kozyra, and F. Micale. 2011. Impacts and adaptation of European crop production systems to climate change. European Journal of Agronomy 34 (2): 96-112.

Orozco-Ramírez, Q., and M. Astier. 2017. Socio-economic and environmental changes related to maize richness in Mexico's central highlands. Agriculture and Human Values 34: 377-391. https:// doi.org/10.1007/s10460-016-9720-5.

Orozco-Ramírez, Q., H.R. Perales, and R.J. Hijmans. 2017. Geographical distribution and diversity of maize (Zea mays L. subsp. mays) races in Mexico. Genetic Resources and Crop Evolution 64: 855865. https://doi.org/10.1007/s10722-016-0405-0.

Orozco-Ramírez, Q., J. Ross-Ibarra, A. Santacruz-Varela, and B. Brush. 2016. Maize diversity associated with social origin and environmental variation in Southern Mexico. Heredity 116: 477-484.

Ortega-Paczka, R. 2003. La diversidad del maíz en México. In Sin maíz no hay país. La diversidad del maíz en México, G. Esteva and C. Marielle, coordinators, 123-154. Conaculta, Museo Nacional de Culturas Populares.

Ortega Paczka, R., and L. Dzib Aguilar. 1992. Recursos genéticos de ma1z para la milpa. In La modernización de la milpa en Yucatán: utopia o realidad, 135-145. Mérida: CICY.

Pautasso, M., G. Aistara, A. Barnaud, S. Caillon, P. Clouvel, O.T. Coomes, M. Delêtre, et al. 2013. Seed exchange networks for agrobiodiversity conservation. A review. Agronomy for Sustainable Development 33 (1): 151-175.

Perales, H.R. 1998. Conservation and evolution of maize in the Valleys of Amecameca and Cuautla valleys of Mexico. $\mathrm{PhD}$ diss., University of California, Davis.

Perales, H.R. 2016. Landrace conservation of maize in Mexico: An evolutionary breeding interpretation. In Enhancing crop genepool use: Capturing wild relative and landrace diversity for crop improvement, ed. N. Maxted, M.E. Dulloo, and B.V. Ford-Lloyd, 271-281. Wallingford: CABI. https://doi.org/10.1079/97817 80646138.0271.

Perales, H.R., B.F. Benz, and S.B. Brush. 2005. Maize diversity and ethnolinguistic diversity in Chiapas, Mexico. Proceedings of the National Academy of Sciences 102: 949-954. https://doi.org/10. 1073/pnas.0408701102.

Perales, H.R., S.B. Brush, and C.O. Qualset. 1998. Agronomic and economic competitiveness of maize landraces and in situ conservation in Mexico. In Farmers gene banks and crop breeding: Economic analyses of diversity in wheat maize and rice, 109-126. Dordrecht: Springer.

Perales, H.R., S.B. Brush, and C.O. Qualset. 2003a. Dynamic management of maize landraces in Central Mexico. Economic Botany 57: 21-34. https://doi.org/10.1663/0013-0001(2003)057[0021: DMOMLI]2.0.CO;2.
Perales, H.R., S.B. Brush, and C.O. Qualset. 2003b. Landraces of maize in Central Mexico: An altitudinal transect. Economic Botany 57: 7-20.

Perales, H.R., and D. Golicher. 2014. Mapping the diversity of maize races in Mexico. PLoS ONE 9: e114657. https://doi.org/10.1371/ journal.pone.0114657.

Perales, H.R., and J.M. Hernández-Casillas. 2005. Diversidad del maíz en Chiapas. México City: Diversidad biológica de Chiapas. Plaza y Valdés, ECOSUR, COCYTECH: 337-355.

Pérez-Ruiz, M.L. 2015. Ser joven y ser maya en un mundo globalizado. Mexico City: Instituto Nacional de Antropología e Historia.

Porter, J.R., and L. Xie. 2014. Food security and food production systems. In Climate change 2014: Impacts, adaptation, and vulnerability. Part A: Global and sectoral aspects. Contribution of working group II to the fifth assessment report of the intergovernmental panel on climate change, 49. Cambridge, New York, NY: Cambridge University Press.

Pressoir, G., and J. Berthaud. 2004. Patterns of population structure in maize landraces from the Central Valleys of Oaxaca in Mexico. Heredity 92: 88-94. https://doi.org/10.1038/sj.hdy.6800387.

Rogé, P., A.R. Friedman, M. Astier, and M. Altieri. 2014. Farmer strategies for dealing with climatic variability: A case study from the Mixteca Alta Region of Oaxaca, Mexico. Agroecology and Sustainable Food Systems 38: 786-811.

Rosenzweig, C., J. Elliott, D. Deryng, A.C. Ruane, C. Müller, A. Arneth, K.J. Boote, et al. 2014. Assessing agricultural risks of climate change in the 21 st century in a global gridded crop model intercomparison. Proceedings of the National Academy of Sciences 111: 3268-3273. https://doi.org/10.1073/pnas.12224 63110.

Schüren, U. 2003. Reconceptualizing the post-peasantry: Household strategies in Mexican Ejidos. Revista Europea de Estudios Latinoamericanos y del Caribe/European Review of Latin American and Caribbean Studies. https://doi.org/10.18352/erlacs.9693.

SIAP. 2011. Cierre de la producción agrícola. Anuario Estadístico de la Producción Agrícola. https://nube.siap.gob.mx/cierreagricola/.

Smale, M. 2005. Valuing crop biodiversity: On-farm genetic resources and economic change. Wallingford: CABI.

Thomas, M., J.C. Dawson, I. Goldringer, and C. Bonneuil. 2011. Seed exchanges, a key to analyze crop diversity dynamics in farmerled on-farm conservation. Genetic Resources and Crop Evolution 58 (3): 321-338.

Tripp, R. 2001. Seed provision \& agricultural development: The institutions of rural change. London: ODI.

Tuxill, J., L. Arias Reyes, L. Latournerie Moreno, V.C. Uicab, and D.I. Jarvis. 2010. All maize is not equal: Maize variety choices and Mayan foodways in rural Yucatán, Mexico. In Pre-Columbian foodways: Interdisciplinary approaches to food, culture, and markets in ancient Mesoamerica, ed. J. Staller and M. Carrasco, 467-486. New York, NY: Springer. https://doi.org/10.1007/9781-4419-0471-3_19.

Ureta, C., C. González-Salazar, E.J. González, E.R. Álvarez-Buylla, and E. Martínez-Meyer. 2013. Environmental and social factors account for Mexican maize richness and distribution: A data mining approach. Agriculture, Ecosystems \& Environment 179: 25-34. https://doi.org/10.1016/j.agee.2013.06.017.

Ureta, C., E. Martínez-Meyer, H.R. Perales, and E.R. Álvarez-Buylla. 2012. Projecting the effects of climate change on the distribution of maize races and their wild relatives in Mexico. Global Change Biology 18: 1073-1082. https://doi.org/10.1111/j.13652486.2011.02607.x.

Van Dusen, and M. Eric. 2000. In situ conservation of crop genetic resources in the Mexican milpa system. AgEcon Search. https:// doi.org/10.22004/ag.econ.11941.

Van Etten, J., and S. De Bruin. 2007. Regional and local maize seed exchange and replacement in the western highlands of 
Guatemala. Plant Genetic Resources: Characterization and Utilization 5: 57-70. https://doi.org/10.1017/S147926210767230X.

Van Heerwaarden, J., F.A. Van Eeuwijk, and J. Ross-Ibarra. 2010. Genetic diversity in a crop metapopulation. Heredity 104: 28-39.

Vermeulen, S.J., D. Dinesh, S.M. Howden, L. Cramer, and P.K. Thornton. 2018. Transformation in practice: A review of empirical cases of transformational adaptation in agriculture under climate change. Frontiers in Sustainable Food Systems. https://doi.org/ 10.3389/fsufs.2018.00065.

Villa, T.C.C., N. Maxted, M. Scholten, and B. Ford-Lloyd. 2005. Defining and identifying crop landraces. Plant Genetic Resources 3 (3): $373-384$

Zimmerer, K.S. 2003. Geographies of seed networks for food plants (potato, ulluco) and approaches to agrobiodiversity conservation in the Andean Countries. Society \& Natural Resources. https:// doi.org/10.1080/08941920309185.

Zizumbo Villarreal, D., C.H. Rasmussen, L.M. Arias Reyes, and S. Terán Contreras. 1992. La modernización de la milpa en Yucatán: utopía o realidad. Mérida, YUC: Centro de Investigación Científica de Yucatán.

Publisher's Note Springer Nature remains neutral with regard to jurisdictional claims in published maps and institutional affiliations.

Marianna Fenzi is a Postdoctoral Research Fellow at the École Polytechnique Fédérale de Lausanne (EPFL). Combining historical analysis with socio-ethnographic approaches, her research examines the evolution of the use and conservation of crop diversity from the Green Revolution until today. Her research aims to contribute to fostering agrobiodiversity in food systems and supporting farmer management of crop diversity.
Paul Rogé is Senior Program Officer at the McKnight Foundation, Minneapolis, Minnesota, USA. He is an agroecologist with an interest in farmer strategies for addressing climate and sustainability challenges in different regions of the world. In recent years, his research has focused on education in urban agroecology and biointensive no-till vegetable farming. He recently coordinated a Certificate of Achievement in Urban Agroecology at Merritt College and the Food Systems Minor at UC Berkeley. He also co-founded two organizations: Agroecology Commons and the Cooperative New School for Urban Studies and Environmental Justice.

Angel Cruz-Estrada is an Associate Scientist at the Centro de Innovación para el Desarrollo Apícola Sustentable en Quintana Roo. He has a multidisciplinary background in Agronomy, Biotechnology, as well as in Participatory Research. His research projects are focused on the impact of agrochemicals on bees and how this could affect honey producers.

John Tuxill is an Associate Professor at Fairhaven College of Interdisciplinary Studies, Western Washington University. Trained as an ethnobotanist, his academic interests center on understanding how people value, utilize and manage plants and the natural world. His field research (ongoing since 2001) has centered on the management of agricultural biodiversity by contemporary Yucatec Maya farmers in central Yucatan state, Mexico.

Devra Jarvis is Coordinator of the Platform for Agrobiodiversity Research (PAR), Honorary Research Fellow at Bioversity International, and adjunct faculty at Washington State University, Crop and Soil Sciences Department, Pullman USA. Dr. Jarvis collaborates with national partners worldwide to develop scientific evidence to support the use of local crop genetic diversity to improve the production and resilience of small-holder farmers. 